Article

\title{
Detailed Characterization of Sympathetic Chain Ganglia (SChG) Neurons Supplying the Skin of the Porcine Hindlimb
}

\author{
Anna Kozłowska $^{1, *}$, Anita Mikołajczyk ${ }^{2}$ (D) and Mariusz Majewski ${ }^{1}$ \\ 1 Department of Human Physiology, Faculty of Medical Sciences, University of Warmia and Mazury Olsztyn, \\ Olsztyn 10-082, Poland; Mariusz.Majewski@uwm.edu.pl \\ 2 Department of Public Health, Epidemiology and Microbiology, Faculty of Medical Sciences, \\ University of Warmia and Mazury Olsztyn, Olsztyn 10-082, Poland; asm@uwm.edu.p1 \\ * Correspondence: kozlowska.anna@uwm.edu.pl; Tel.: +48-89-524-5304; Fax: +48-89-523-5307
}

Received: 23 May 2017; Accepted: 1 July 2017; Published: 7 July 2017

\begin{abstract}
It is generally known that in the skin sympathetic fibers innervate various dermal structures, including sweat glands, blood vessels, arrectores pilorum muscles and hair follicles. However, there is a lack of data about the distribution and chemical phenotyping of the sympathetic chain ganglia (SChG) neurons projecting to the skin of the pig, a model that is physiologically and anatomically very representative for humans. Thus, the present study was designed to establish the origin of the sympathetic fibers supplying the porcine skin of the hind leg, and the pattern(s) of putative co-incidence of dopamine- $\beta$-hydroxylase $(\mathrm{D} \beta \mathrm{H})$ with pituitary adenylate cyclase-activating polypeptide (PACAP), somatostatin (SOM), neuronal nitric oxide synthase, substance $\mathrm{P}$, vasoactive intestinal peptide, neuropeptide Y (NPY), leu5-enkephalin and galanin (GAL) using combined retrograde tracing and double-labeling immunohistochemistry. The Fast Blue-positive neurons were found in the $\mathrm{L}_{2}-\mathrm{S}_{2}$ ganglia. Most of them were small-sized and contained $\mathrm{D} \beta \mathrm{H}$ with PACAP, SOM, NPY or GAL. The findings of the present study provide a detailed description of the distribution and chemical coding of the SChG neurons projecting to the skin of the porcine hind leg. Such data may be the basis for further studies concerning the plasticity of these ganglia under experimental or pathological conditions.
\end{abstract}

Keywords: skin-projecting neurons; chemical coding; sympathetic chain ganglia; pig

\section{Introduction}

It is generally known that skin is mainly innervated by sympathetic nerve fibers, with an additional complement of autonomic nerve fibers. In the human, autonomic nerve fibers derive from two sources: sympathetic and, rarely, parasympathetic neurons [1]. The sympathetic innervations of the skin was characterized in humans [2-4] and other mammals, such as the rat [5], guinea pig [6], cat [7], rabbit [8], dog [9] and pig [4]. These fibers innervate dermis, blood and lymphatic vessels, arteriovenous anastomoses, erector pili muscles, apocrine and eccrine glands, as well as hair follicles [10]. However, they are involved principally in the regulation of blood flow by two distinct branches: a noradrenergic vasoconstrictor branch and a cholinergic active vasodilator branch [11]. Noradrenergic vasoconstrictor nerves are tonically active in normothermic environments [12] and they increase activity during cold exposure, secreting norepinephrine, which acts on postsynaptic $\alpha_{1}$ - and $\alpha_{2}$-receptors [13-15] to decrease skin blood flow [16]. Several studies have also shown that sympathetic innervations of the skin, in addition to their basic function in the blood flow, also plays an important role in the mechanisms of radicular and neuropathic pain [17-20]. 
In humans and cats, skin-projecting sympathetic neurons supplying the lower leg/hind paw were distributed in a distinct set of sympathetic chain ganglia (SChG). For instance, in humans such neurons were found in $\mathrm{L}_{1}-\mathrm{L}_{4} \mathrm{SChG}$ [21], whereas in cats they were found within $\mathrm{L}_{6}-\mathrm{S}_{2}$ ganglia [22].

Previous studies in the pig showed that the majority of the postganglionic SChG neurons projecting to different organs, i.e., ovary [23], colon [24,25], urinary bladder [26,27] or pylorus [28] are noradrenergic, i.e., they express enzymes participating in the synthesis of noradrenaline-tyrosine hydroxylase $(\mathrm{TH})$ and dopamine $\beta$-hydroxylase $(\mathrm{D} \beta \mathrm{H})$. Furthermore, there is strong evidence indicating that postganglionic sympathetic perikarya, in addition to classic catecholaminergic transmitter (noradrenaline), could contain other biologically active substances, such as: substance (SP), galanin (GAL), neuropeptide Y (NPY), neuronal nitric oxide synthase (nNOS), somatostatin (SOM), leu5-enkephalin (LENK), vasoactive intestinal peptide (VIP) or pituitary adenylate cyclase-activating polypeptide (PACAP) [24-29]. It was also strongly suggested that some of these markers co-operate with noradrenaline in cutaneous active vasoconstriction [30] while others participate in active vasodilation of cutaneous arterioles [31]. However, until now, little has been known about the distribution and chemical coding of sympathetic skin-projecting neurons supplying the porcine hind leg. Such data could be of great importance because the pig shows distinct anatomical, physiological, biochemical and immunological similarities to humans [32], which makes it a more suitable model than rodents [33] for studying human skin diseases [34]. Therefore, the present experiment was aimed at: (1) identifying the distribution pattern of retrogradely-labeled sympathetic SChG neurons involved in skin innervations of porcine hindlimb; and (2) elucidating the chemical phenotypes of noradrenergic SChG neurons using double-immunofluorescence.

\section{Results}

\subsection{The Number and Distribution Pattern of Skin-Projecting Neurons with in the Porcine Sympathetic Chain Ganglia (SChG)}

As revealed by the retrograde tract-tracing procedure, the SChG neurons innervating skin of the porcine hind leg were distributed in the left lumbar $\left(\mathrm{L}_{2}-\mathrm{L}_{6}\right)$ and sacral $\left(\mathrm{S}_{1}-\mathrm{S}_{2}\right) \mathrm{SChG}$ (Figure 1).

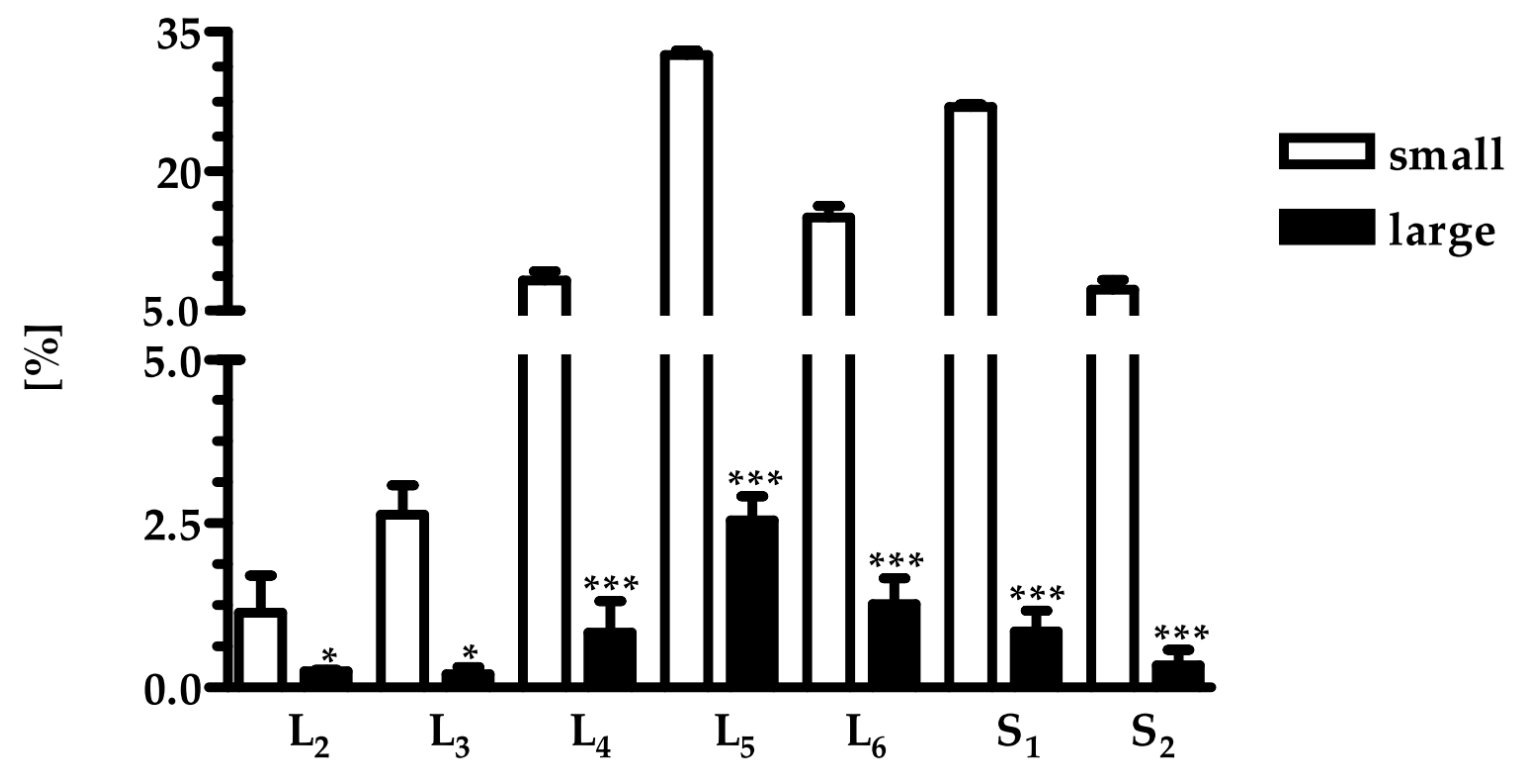

Figure 1. Bar diagram showing the segmental distribution of the skin-projecting neurons in porcine sympathetic chain ganglia following injection of Fast Blue in to the skin. Distribution of the skin-projecting neurons $(n=4)$. Bars represent mean number of small-(hollow bars) and large-sized (filled bars) neurons \pm SEM located in left ganglia. Asterisks mark statistically significant differences: ${ }^{*} p<0.05 ;{ }^{* * *} p<0.001$. 
The contralateral SChG did not contain Fast Blue (FB)-labeled neurons. Among lumbar segments the highest number of these cells was observed in $\mathrm{L}_{5}$, while in the sacral region in $\mathrm{S}_{1}$. The total number of $\mathrm{FB}^{+}$neurons in $\mathrm{L}_{2}-\mathrm{S}_{2}$ region was $3231 \pm 359$, and $73.7 \pm 14.0 \%$ of them were located in the lumbar segments. Lumbar and sacral skin-projecting neurons were similar in size $\left(782.1 \pm 374.6 \mu \mathrm{m}^{2}\right.$ vs. $676.8 \pm 224.6 \mu^{2}$ ). Relative frequency of individual subclasses of porcine skin-projecting SChG neurons, defined by their cross-sectional area is shown in Figure $2 \mathrm{a}, \mathrm{b}$.

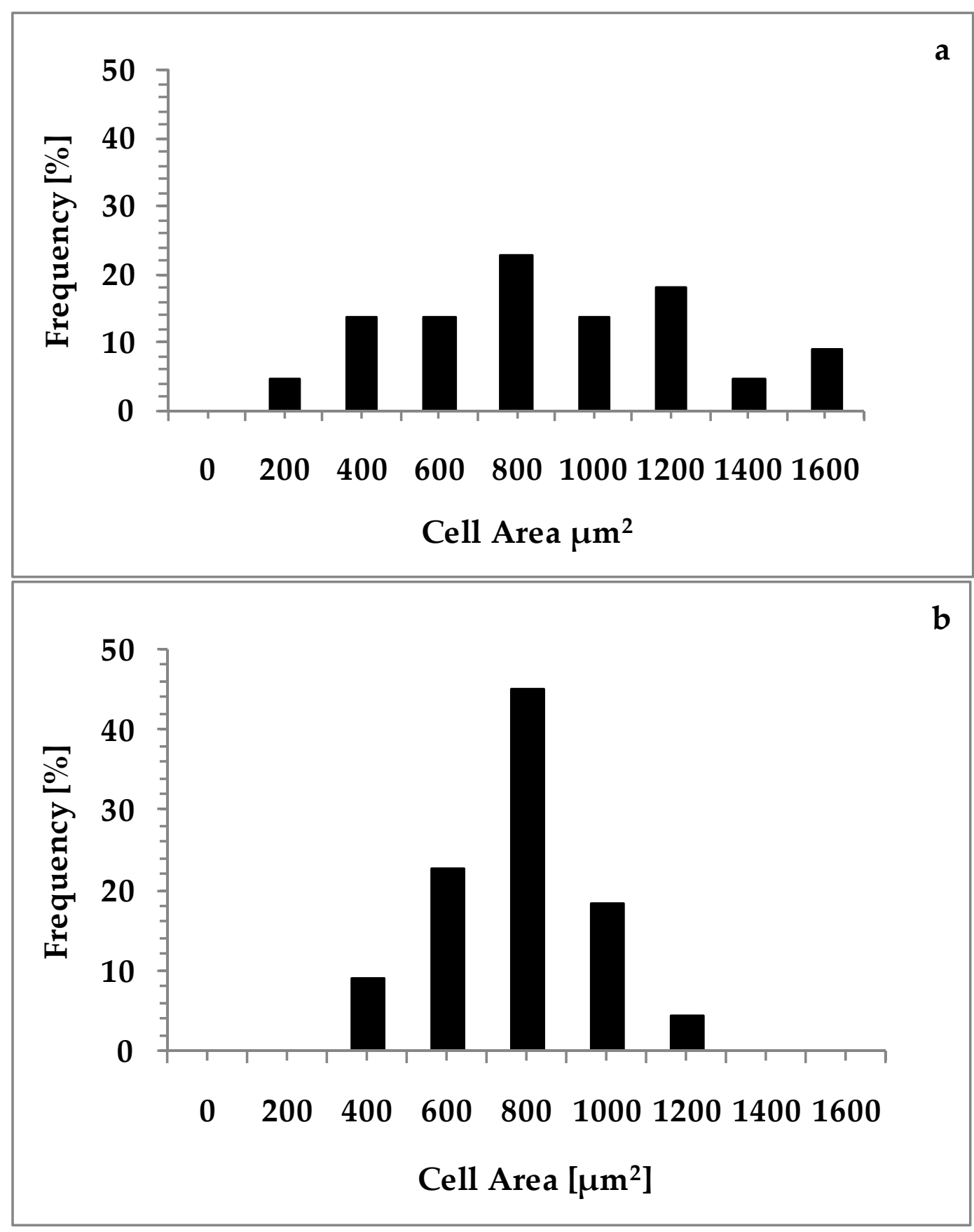

Figure 2. Histogram showing the relative frequency of individual subclasses of porcine skin-projecting SChG neurons, defined by their cross-sectional area in: lumbar (a); and sacral (b) SChGs ( $n=200$ neurons were measured for each histogram). 
The majority of FB neurons belonged to the population of small-sized neurons, while large-sized cells was less numerous (Figure 1). Relative frequency of cell diameter-depending classes of different the skin-projecting SChG neurons is shown in Figure 3.

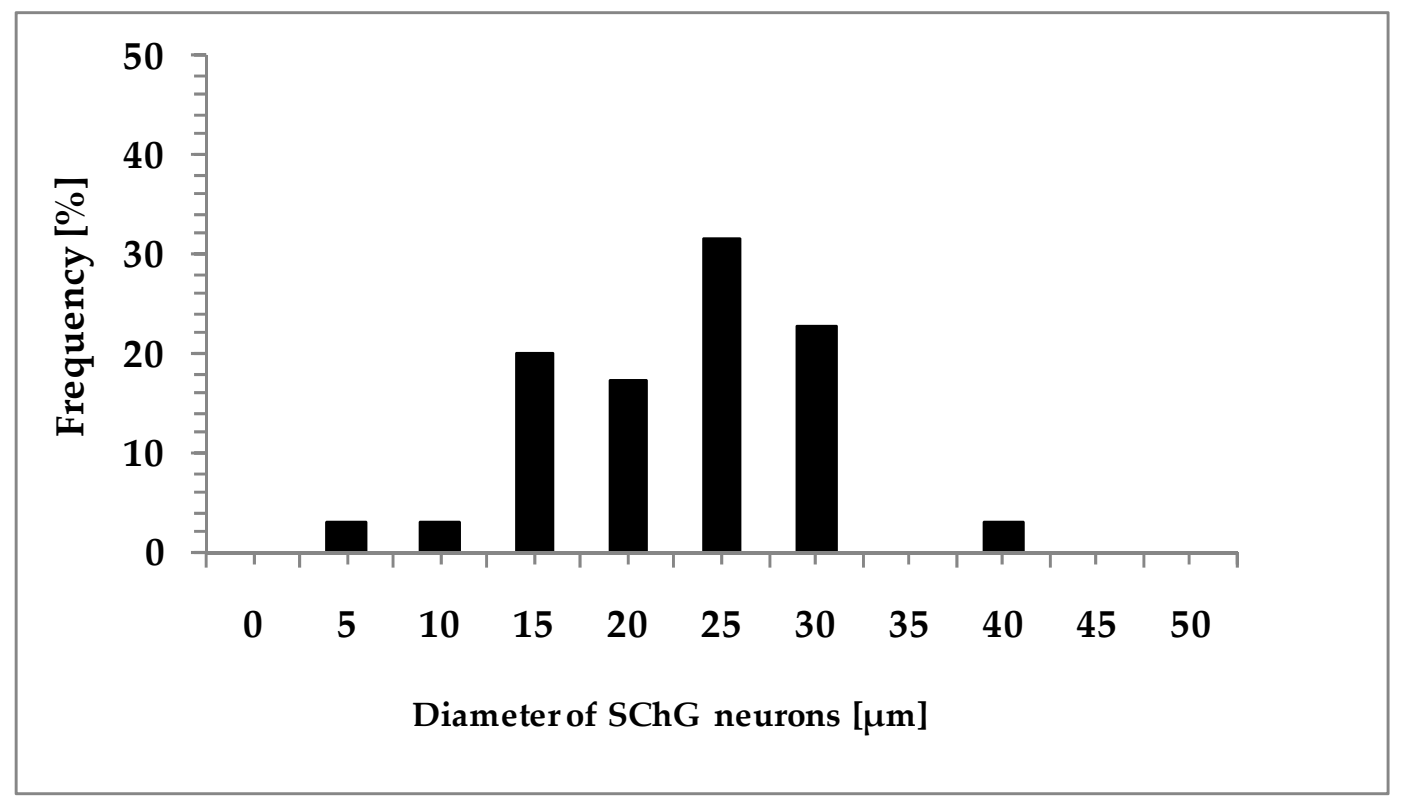

Figure 3. Relative frequency of cell diameter-depending classes of different the skin-projecting SChG neurons (based on $n=400$ measured cells).

When the distribution of the FB neurons was compared within four subdomains of the SChG the results were as follows (Figure 4a,b).

The small-sized cells were more often located in the cranio-dorsal subdomain $(26.6 \pm 0.4 \%)$ than in the cranio-ventral subdomain $(21.4 \pm 0.6 \%)$ of lumbar SChG. The percentage of these cells was also higher in the cranio-dorsal subdomain of lumbar SChG when compared to the sacral SChG $(21.6 \pm 2.2 \%)$. In the sacral SChG the highest percentage of small-sized neurons was found in the caudo-dorsal subdomain ( $32.0 \pm 1.9 \%)$, especially when compared to the lumbar SChG $(24.6 \pm 0.9 \%)$. The distribution of small-sized neurons in the cranio- $(22.4 \pm 0.6 \%$ vs. $19.6 \pm 1.3 \%)$ and caudo-ventral $(26.6 \pm 0.9 \%$ vs. $26.8 \pm 1.3 \%)$ subdomains of the lumbar and sacral SChG was similar (Figure $4 a$ ).

The distribution patterns of the large-sized neurons within the specific subdomains of the lumbar and sacral SChG were quite different (Figure $4 \mathrm{~b}$ ). For example, large-sized neurons in the both lumbar and sacral SChG were significantly more numerous in the cranio-dorsal $(33.3 \pm 3.9 \%, 36.2 \pm 2.2 \%$; respectively) than cranio-ventral subdomains $(20.0 \pm 1.9 \%, 20.3 \pm 2.6 \%$; respectively). Moreover, in the caudo-ventral subdomain of sacral SChG, the percentage of these cells $(29.4 \pm 3.5 \%)$ was significantly higher when compared to the caudo-dorsal subdomain $(14.0 \pm 2.6 \%)$, whereas the percentage of large-sized cells localized in the latter subdomain of the lumbar SChG $(25.7 \pm 2.5 \%)$ was higher than in the sacral SChG $(14.0 \pm 2.6 \%)$. There was no statistically significant difference in the frequency of these cells between lumbar and sacral SChG in the caudo-ventral subodmain ( $20.8 \pm 0.6 \%$ vs. $29.4 \pm 3.5 \%)$. Additionally, the frequency of large-sized cells in the cranio-dorsal or cranio-ventral subdomains of the lumbar and sacral SChG was similar. 


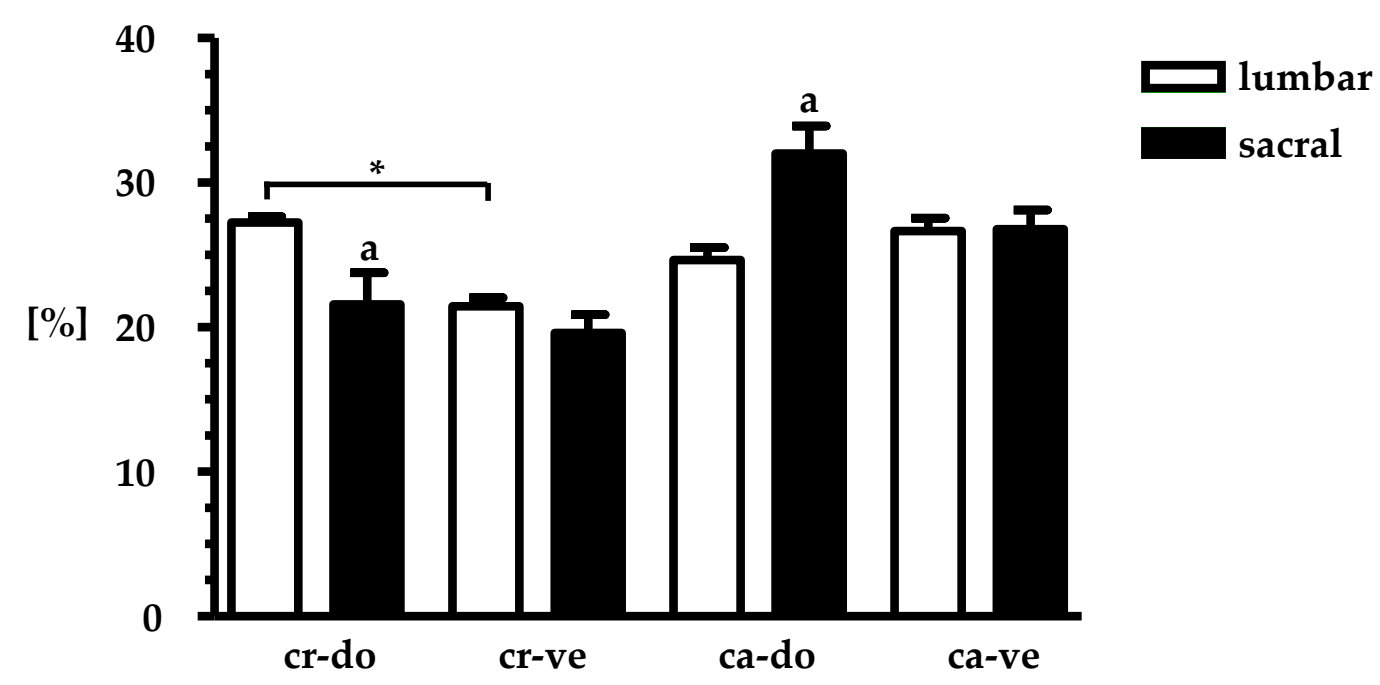

b

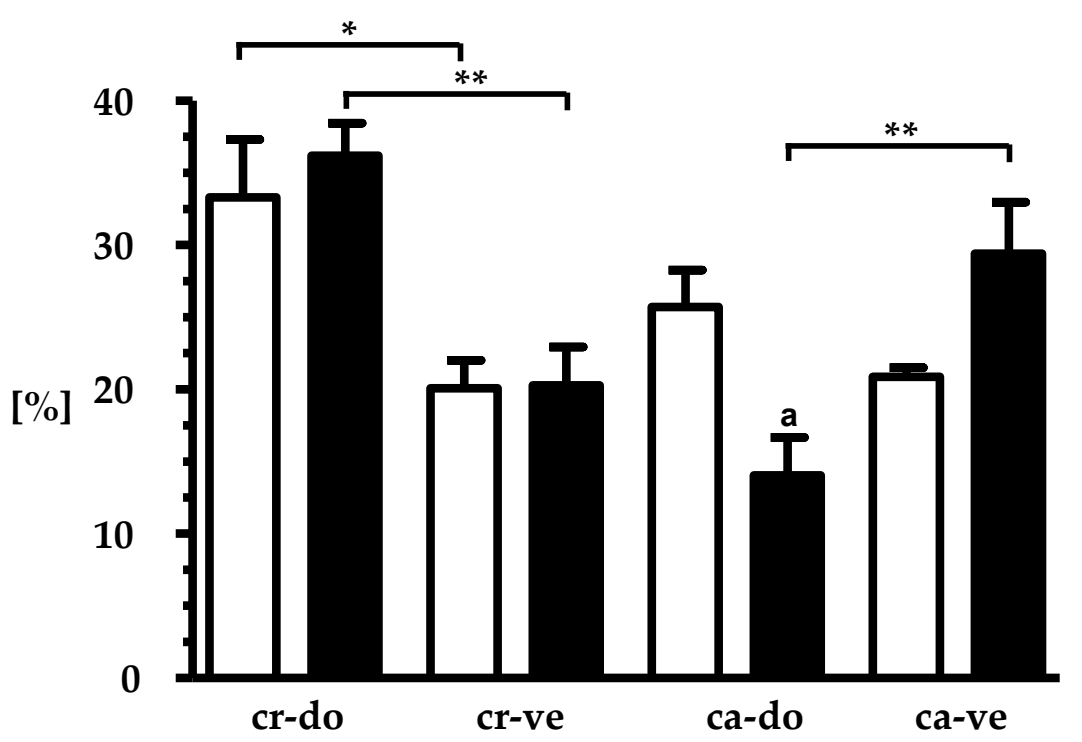

Figure 4. Relative frequency (mean $\pm \mathrm{SEM} ; n=4$ ) of skin-projecting small- and large-diameter neurons in particular subdomains of the lumbar ((a) $\mathrm{L}_{2}-\mathrm{L}_{6}$; open bars); and sacral ((b) $\mathrm{S}_{1}-\mathrm{S}_{2}$; solid bars) SChGs studied. ${ }^{\mathbf{a}}$ Indicates statistically-significant differences $(p<0.05)$ between the lumbar and sacral SChGs. ${ }^{*} p<0.05,{ }^{* *} p<0.01$ indicate statistically-significant differences between the cranio-dorsal (cr-do) and cranio-ventral (cr-ve) or caudo-dorsal (ca-do) and caudo-ventral (ca-ve) subdomains of lumbar and sacral SChGs.

2.2. Neurochemical Phenotypes of Skin-Projecting Neurons within the Porcine Sympathetic China Ganglia (SChG)

All details concerning neurochemical phenotypes of skin-projecting neurons within the porcine SChG are demonstrated in Tables 1 and 2. 
Table 1. Percentages of retrogradely labeled small- and large-sized neurons in the porcine lumbar $\left(\mathrm{L}_{4}-\mathrm{L}_{6}\right)$ sympathetic chine ganglia projecting to the skin of the hindlimb.

\begin{tabular}{|c|c|c|c|c|c|c|c|c|c|c|c|c|}
\hline \multirow[b]{2}{*}{ Substances } & \multicolumn{12}{|c|}{ Ganglia } \\
\hline & $\mathrm{FB}^{+} / \mathrm{D} \beta \mathrm{H}^{+} / \mathrm{S}^{+}$ & $\begin{array}{c}\mathrm{L}_{4} \\
\mathrm{FB}^{+} / \mathrm{D} \beta \mathrm{H}^{+} / \mathrm{S}^{-} \quad \mathrm{FB}\end{array}$ & $\mathrm{B}^{+} / \mathrm{D} \beta \mathrm{H}^{-} / \mathrm{S}^{+}$ & $\mathrm{FB}^{+} / \mathrm{D} \beta \mathrm{H}^{-} / \mathrm{S}^{-}$ & $-\mathrm{FB}^{+} / \mathrm{D} \beta \mathrm{H}^{+} / \mathrm{S}^{+}$ & $\begin{array}{r}\mathbf{L}_{5} \\
\mathrm{FB}^{+} / \mathrm{D} \beta \mathrm{H}^{+} / \mathrm{S}^{-}\end{array}$ & $\mathrm{FB}^{+} / \mathrm{D} \beta \mathrm{H}^{-} / \mathrm{S}^{+}$ & $/ \mathrm{S}^{+} \mathrm{FB}^{+} / \mathrm{D} \beta \mathrm{H}^{-} / \mathrm{S}^{-}$ & $\mathrm{FB}^{+} / \mathrm{D} \beta \mathrm{H}^{+} / \mathrm{S}^{+}$ & $\begin{array}{c}\mathrm{L}_{6} \\
\mathrm{FB}^{+} / \mathrm{D} \beta \mathrm{H}^{+} / \mathrm{S}^{-}\end{array}$ & $\mathrm{FB}^{+} / \mathrm{D} \beta \mathrm{H}^{-} / \mathrm{S}^{+}$ & $S^{+} \quad \mathrm{FB}^{+} / \mathrm{D} \beta \mathrm{H}^{-} / \mathrm{S}^{-}$ \\
\hline \multirow[t]{2}{*}{ PACAP } & $26.0 \pm 1.3$ & $\begin{array}{r}\text { Small cells } \\
49.7 \pm 1.8 \\
\text { Large cells }\end{array}$ & $\begin{array}{l}\text { ls } \\
0.3 \pm 0.3 \\
\text { ls }\end{array}$ & $23.8 \pm 1.3$ & $49.5 \pm 2.3 \mathrm{a}(p<0.001)$ & $\begin{array}{c}\text { Small cells } \\
34.8 \pm 4.6 \text { a ( } p<0.05) \\
\text { Large cells }\end{array}$ & $0.6 \pm 0.6$ & $14.9 \pm 4.0$ & $33.1 \pm 1.9^{c(p<0.001)}$ & $\begin{array}{c}\text { Small cells } \\
39.6 \pm 3.4 \\
\text { Large cells }\end{array}$ & 0 & $27.3 \pm 1.9^{c(p<0.01)}$ \\
\hline & $18.1 \pm 1.7^{*}$ & $61.4 \pm 1.7 * * * *$ & 0 & $20.5 \pm 0.5$ & $36.1 \pm 7.3$ & $57.6 \pm 4.8$ & 0 & $6.2 \pm 6.2$ & $20.9 \pm 0.5$ & $58.1 \pm 1.0$ & 0 & $20.9 \pm 0.5$ \\
\hline \multirow[t]{2}{*}{ SOM } & $33.7 \pm 2.2$ & $\begin{array}{r}\text { Small cells } \\
52.8 \pm 2.9 \\
\text { Large cells }\end{array}$ & $\begin{array}{l}\text { ls } \\
1.0 \pm 0.6\end{array}$ & $12.4 \pm 1.9$ & $23.5 \pm 0.7 \mathrm{a}(p<0.001)$ & $\begin{array}{c}\text { Small cells } \\
62.6 \pm 1.3 \\
\text { Large cells }\end{array}$ & $0.3 \pm 0.3$ & $13.6 \pm 1.2$ & $17.4 \pm 0.9^{\mathrm{b}(p<0.001) ; \mathrm{c}(p<0.001)}$ & $\begin{array}{c}\text { Small cells } \\
62.9 \pm 3.5 \\
\text { Large cells }\end{array}$ & $2.7 \pm 1.7$ & $16.9 \pm 1.4$ \\
\hline & $23.9 \pm 3.2 * *$ & $63.3 \pm 1.9^{*}$ & 0 & $12.8 \pm 4.7$ & $25.1 \pm 0.02$ & $43.9 \pm 2.0 * * * ; a(p<0.001)$ & 0 & $31.0 \pm 2.0 * * * ; \mathrm{a}(p<0.001)$ & $34.1 \pm 1.3 * * * ; b(p<0.011) ;(p<0.05)$ & $50.3 \pm 0.6^{* *, b} b(p<0.01)$ & 0 & $15.6 \pm 0.7^{c}(p<0.011)$ \\
\hline \multirow[t]{2}{*}{ nNOS } & $11.2 \pm 0.6$ & $\begin{array}{r}\text { Small cells } \\
68.8 \pm 2.7 \\
\text { Large cells }\end{array}$ & $\begin{array}{ll}\text { ls } & \\
\text { ls } & 0\end{array}$ & $20.0 \pm 2.6$ & $15.9 \pm 0.9^{\mathrm{a}(p<0.05)}$ & $\begin{array}{r}\text { Small cells } \\
73.6 \pm 0.8 \\
\text { Large cells }\end{array}$ & 0 & $10.4 \pm 0.6^{\mathrm{a}(p<0.02)}$ & $15.8 \pm 0.4^{\mathrm{b}(p<0.05)}$ & $\begin{array}{c}\text { Small cells } \\
68.9 \pm 1.1 \\
\text { Large cells }\end{array}$ & $0.7 \pm 0.4$ & $14.5 \pm 1.8$ \\
\hline & $17.9 \pm 1.9^{* *}$ & $62.8 \pm 1.5$ & 0 & $19.2 \pm 1.0$ & $11.4 \pm 0.7 *$, a $(p<0.01)$ & $53.6 \pm 1.3 * * * a$ a $(p<0.01)$ & 0 & $35.0 \pm 1.6^{* * *, a}$ a $(p<0.001)$ & $11.7 \pm 0.5^{* * *}$ & $\begin{array}{c}44.2 \pm 0.7 \\
* * * ; b(p<0.001) ; c(p<0.01)\end{array}$ & 0 & $\begin{array}{c}44.1 \pm 0.8 \\
* * * ; b(p<0.001) ; c(p<0.01)\end{array}$ \\
\hline \multirow{4}{*}{ SP } & & Small cells & & & & Small cells & & & & Small cells & & \\
\hline & $21.9 \pm 0.5$ & $59.4 \pm 0.8$ & 0 & $18.7 \pm 0.6$ & $22.2 \pm 0.9$ & $57.7 \pm 0.4$ & 0 & $19.9 \pm 0.5$ & $35.1 \pm 0.4 \mathrm{~b}(p<0.001)$ & $56.3 \pm 1.0$ & $0.5 \pm 0.5$ & $\begin{array}{c}8.1 \pm 0.9 \\
\mathrm{~b}(p<0.001) ; \mathrm{c}(p<0.001)\end{array}$ \\
\hline & & Large cells & & & & Large cells & & & & Large cells & & \\
\hline & $7.8 \pm 0.3^{* * *}$ & $70.8 \pm 0.6^{*}$ & 0 & $21.4 \pm 0.5^{*}$ & 0 & $56.2 \pm 5.5^{\mathrm{a}(p<0.01)}$ & 0 & $43.7 \pm 5.5^{* * * ; a}(p<0.001)$ & $12.1 \pm 0.3^{* * * ; b}(p<0.001)$ & $54.5 \pm 0.7^{b(p<0.01)}$ & 0 & $\begin{array}{c}33.3 \pm 0.4 \\
* * * ; b(p<0.05) ; c(p<0.05)\end{array}$ \\
\hline \multirow[t]{2}{*}{ VIP } & $19.5 \pm 1.1$ & $\begin{array}{r}\text { Small cells } \\
70.0 \pm 1.2 \\
\text { Large cells }\end{array}$ & $\begin{array}{ll}\text { ls } & \\
\text { ls } & 0\end{array}$ & $10.4 \pm 0.4$ & $20.0 \pm 0.8$ & $\begin{array}{c}\text { Small cells } \\
73.5 \pm 0.4 \\
\text { Large cells }\end{array}$ & 0 & $6.5 \pm 0.4$ & $25.5 \pm 1.5^{\mathrm{b}(p<0.01) ; \mathrm{c}(p<0.05)}$ & $\begin{array}{c}\text { Small cells } \\
64.9 \pm 1.0 c^{(p<0.01)} \\
\text { Large cells }\end{array}$ & 0 & $9.6 \pm 0.5$ \\
\hline & $3.6 \pm 1.1^{* * *}$ & $94.6 \pm 2.1 * *$ & 0 & $1.8 \pm 1.8^{* * *}$ & $21.7 \pm 0.6^{\mathrm{a}(p<0.001)}$ & $33.9 \pm 3.2^{* * *, a}(p<0.001)$ & 0 & $44.4 \pm 1.1^{* * *, a} a(p<0.001)$ & $9.2 \pm 0.8^{* * *, b}(p<0.01) ; c(p<0.001)$ & $60.3 \pm 0.8^{\mathrm{b}(p<0.001) ; \mathrm{c}(p<0.001)}$ & 0 & $\begin{array}{c}30.5 \pm 1.0 \\
* * * ; b(p<0.001) ; c(p<0.001)\end{array}$ \\
\hline \multirow{4}{*}{ NPY } & & Small cells & & & & Small cells & & & & Small cells & & \\
\hline & $37.6 \pm 0.5$ & $59.1 \pm 1.4$ & $0.2 \pm 0.2$ & $3.1 \pm 0.7$ & $26.9 \pm 1.0^{\mathrm{a}(p<0.01)}$ & $68.9 \pm 1.2$ & $1.0 \pm 1.0$ & $2.7 \pm 2.7$ & $18.3 \pm 0.2^{b(p<0.001) ; c(p<0.05)}$ & $70.8 \pm 1.3^{b(p<0.001)}$ & 0 & $\begin{array}{l}10.8 \pm 1.1 \\
\mathrm{~b}(p<0.05) ;(p<0.05)\end{array}$ \\
\hline & & Large cells & & & & Large cells & & & & Large cells & & \\
\hline & $21.8 \pm 0.8 * * *$ & $58.2 \pm 0.9$ & $2.7 \pm 2.7$ & $17.2 \pm 2.2$ & $55.8 \pm 3.9^{* * * * a} \mathrm{a}(p<0.001)$ & $30.2 \pm 1.1 * * * ;(p<0.001)$ & $2.7 \pm 2.7$ & $11.2 \pm 0.7^{*}$ & $\begin{array}{c}32.9 \pm 1.4 \\
* * * ; \mathrm{b}(p<0.001) ; \mathrm{c}(p<0.001)\end{array}$ & $51.5 \pm 0.8 * * * ;(p<0.001)$ & 0 & $15.4 \pm 0.9$ \\
\hline \multirow[t]{2}{*}{ LENK } & $1.3 \pm 0.6$ & $\begin{array}{r}\text { Small cells } \\
88.8 \pm 1.5 \\
\text { Large cells }\end{array}$ & $\begin{array}{ll}\text { ls } & \\
\text { ls } & 0\end{array}$ & $9.9 \pm 0.8$ & $3.4 \pm 0.6$ & $\begin{array}{r}\text { Small cells } \\
82.2 \pm 1.2 \\
\text { Large cells }\end{array}$ & 0 & $14.1 \pm 1.0^{\mathrm{a}(p<0.05)}$ & $1.8 \pm 0.9$ & $\begin{array}{c}\text { Small cells } \\
85.8 \pm 2.4 \\
\text { Large cells }\end{array}$ & 0 & $12.4 \pm 0.4$ \\
\hline & $1.6 \pm 1.0$ & $78.4 \pm 3.7^{*}$ & 0 & $\underset{* * *}{20.0 \pm 0.6}$ & $11.4 \pm 0.7^{* * * ;} \mathrm{a}(p<0.001)$ & $77.1 \pm 0.4$ & 0 & $11.4 \pm 0.7^{\mathrm{a}(p<0.001)}$ & $0.5 \pm 0.5^{c(p<0.001)}$ & $87.8 \pm 1.5$ & 0 & $11.5 \pm 1.2$ \\
\hline \multirow[t]{2}{*}{ GAL } & $26.6 \pm 3.6$ & $\begin{array}{c}\text { Small cells } \\
63.0 \pm 3.7 \\
\text { Large cells }\end{array}$ & ls 1 & $10.3 \pm 1.3$ & $9.0 \pm 0.2^{\mathrm{a}(p<0.001)}$ & $\begin{array}{r}\text { Small cells } \\
80.7 \pm 2.2^{\mathrm{a}(p<0.001)} \\
\text { Large cells }\end{array}$ & 0 & $10.0 \pm 0.4$ & $14.3 \pm 0.2^{b(p<0.001)}$ & $\begin{array}{c}\text { Small cells } \\
71.0 \pm 0.4 \mathrm{~b}(p<0.05) ; \mathrm{c}(p<0.05) \\
\text { Large cells }\end{array}$ & 0 & $14.5 \pm 0.5^{\mathrm{b}(p<0.05)}$ \\
\hline & 0 & $85.1 \pm 1.1 * * *$ & 0 & $14.8 \pm 1.1^{*}$ & $13.5 \pm 0.6$ & $73.6 \pm 0.9^{\mathrm{a}(p<0.01)}$ & 0 & $12.8 \pm 0.4$ & $11.5 \pm 0.2^{\prime}$ & $73.9 \pm 0.9^{\mathfrak{b}(p<0.01)}$ & 0 & $14.5 \pm 0.9$ \\
\hline
\end{tabular}

Data were expressed as mean \pm standard error ( \pm SEM). S- studied substance (NPY, SOM, VIP, etc.). ${ }^{*}, * *$, and ${ }^{* * *}$ indicate statistically-significant differences $(p<0.05, p<0.01$, and $p<0.001$, respectively) between the small- and large-sized neurons in the SChGs. ${ }^{a}$ Indicates statistically-significant differences $(p<0.05, p<0.01$, and $p<0.001)$ between the $\mathrm{L}_{4}$ and $\mathrm{L}_{5}$ segments of

the SChG. ${ }^{\mathrm{b}}$ Indicates statistically-significant differences $(p<0.05, p<0.01$, and $p<0.001)$ between the $\mathrm{L}_{4}$ and $\mathrm{L}_{6}$ segments of the SChG. ${ }^{c}$ indicates statistically-significant differences $(p<0.05, p<0.01, p<0.001)$ between the $\mathrm{L}_{5}$ and $\mathrm{L}_{6}$ segments of the SChG. The total number of cells counted was 6791 . The mean number of cells counted for each combination was $(p<0.05, p<0$
$289 \pm 16.2$ 
Table 2. Percentages of retrogradely labeled small and large cells in the porcine sacral $\left(\mathrm{S}_{1}-\mathrm{S}_{2}\right)$ sympathetic chine ganglia projecting to the skin of the hindlimb.

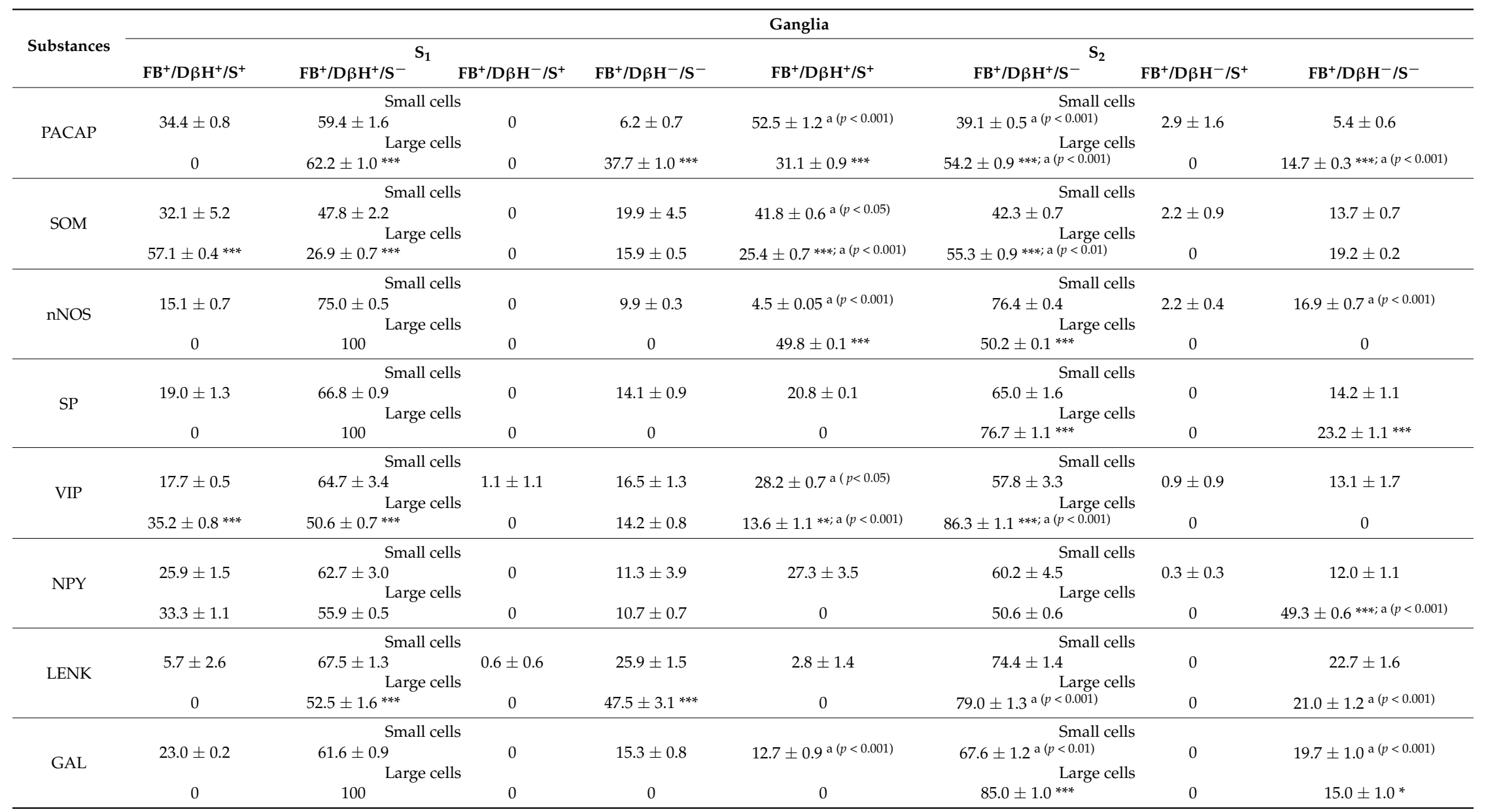

Data were expressed as mean \pm standard error ( $($ SEM). S—studied substance (NPY, SOM, VIP, etc.) * ** and *** indicate statistically-significant differences $(p<0.05, p<0.01$, and $p<0.001$, respectively) between the small- and large-sized neurons in the SChGs. ${ }^{a}$ Indicates statistically-significant differences $(p<0.05, p<0.01$, and $p<0.001)$ between the $\mathrm{S}_{1}$ and $\mathrm{S}_{2}$ segments of the SChG. The total number of cells counted was 2670. The mean number of cells counted for each combination was $166 \pm 58.1$. 
The morphology and characteristic features of double-immunolabeled elements are visualized in Figures 5 and 6.
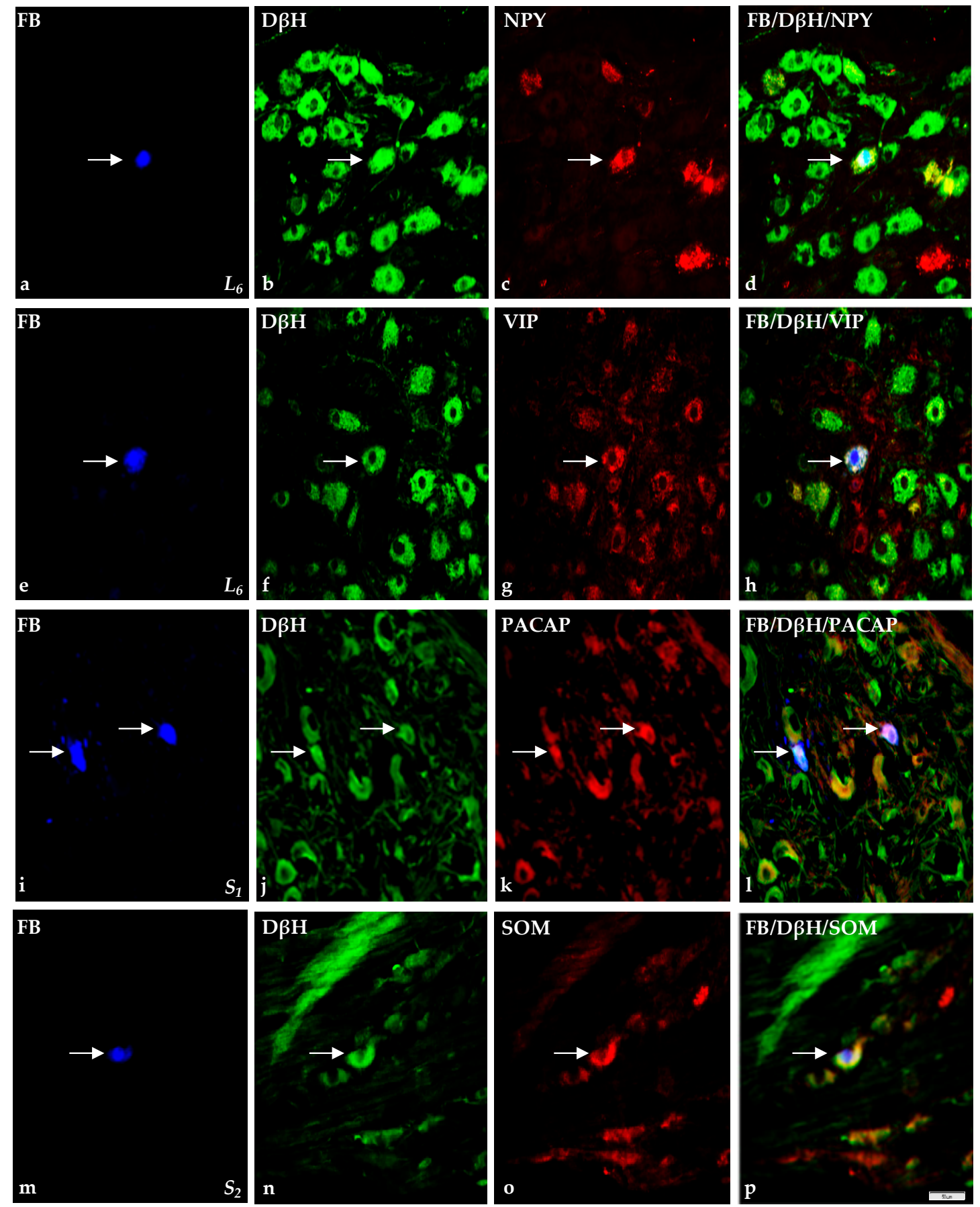

Figure 5. Representative images of sympathetic chain ganglia skin-projecting neurons in porcine skin hind leg. The arrow indicates Fast blue-positive $\left(\mathrm{FB}^{+}\right)$skin perikaryon containing examined

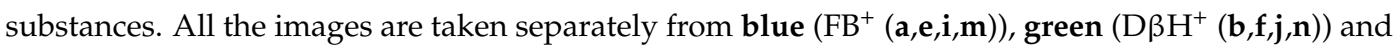
red (positive for: NPY (c); VIP (g); PACAP (k); and SOM (o)) fluorescent channels. Microphotographs $\mathbf{d}, \mathbf{h}, \mathbf{l}, \mathbf{p}$ showing the over position of all three channels simultaneously. In $\mathrm{L}_{6}$ ganglion, $\mathrm{FB}^{+}$small-sized neurons $(\mathbf{a}, \mathbf{e})$ which were simultaneously $\mathrm{D}_{3} \mathrm{H}^{+}(\mathbf{b}, \mathbf{f})$ as well as $\mathrm{NPY}^{+}(\mathbf{c})$ and $\mathrm{VIP}^{+}(\mathbf{g})$. Two small-sized $\mathrm{FB}^{+}$neurons (i) containing simultaneously $\mathrm{D} \beta \mathrm{H}(\mathbf{j})$; and PACAP (k) in $\mathrm{S}_{1}$ SChG. Visible one $\mathrm{FB}^{+}$ small-sized neuron $(\mathbf{m})$ containing D $\beta H(\mathbf{n})$ and SOM (o) in $\mathrm{S}_{2}$ SChG. Scale bar $=50 \mu \mathrm{m}$. 

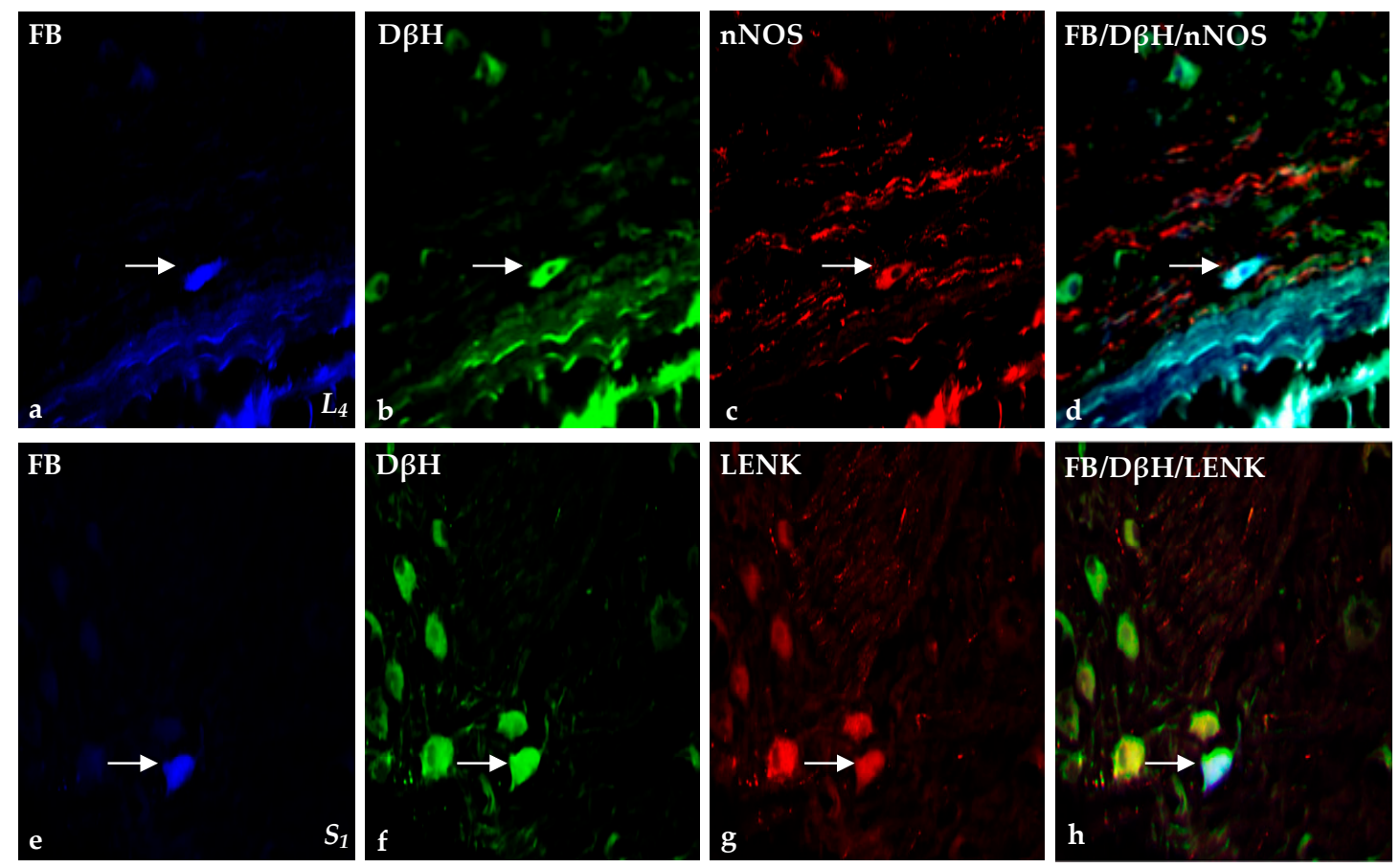

FB/D $\beta$ H/LENK
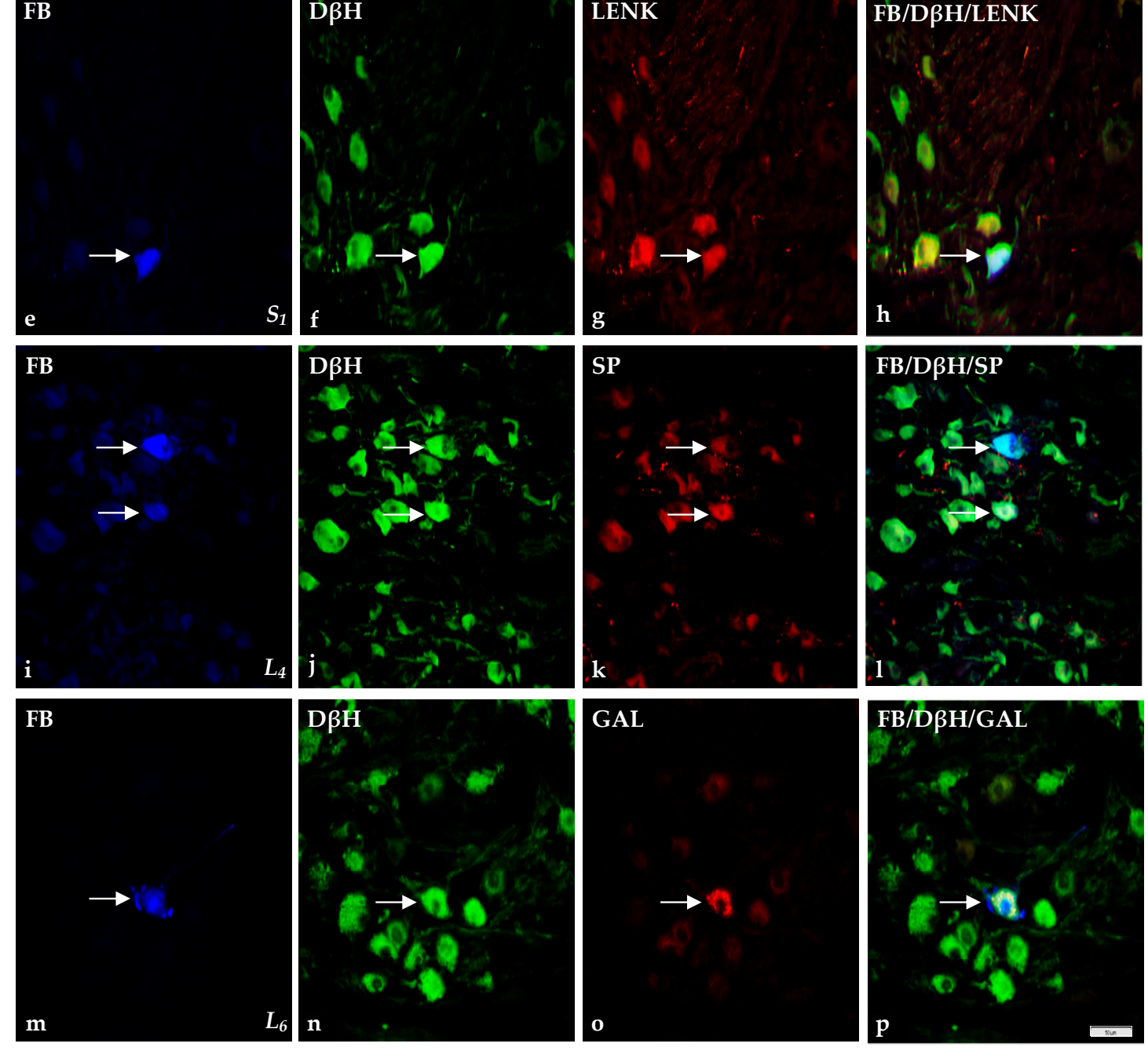

Figure 6. Representative images of sympathetic chain ganglia skin-projecting neurons in porcine skin hind leg. The arrow indicates Fast blue-positive $\left(\mathrm{FB}^{+}\right)$skin perikaryon containing examined substances. All the images are showed separately from blue (FB-positive $(\mathbf{a}, \mathbf{e}, \mathbf{i}, \mathbf{m}))$, green $(D \beta H$-positive $(\mathbf{b}, \mathbf{f}, \mathbf{j}, \mathbf{n})$ ) and red (positive for nNOS (c); LENK (g); SP (k); and GAL (o)) fluorescent channels. Microphotographs $\mathbf{d}, \mathbf{h}, \mathbf{l}, \mathbf{p}$ showing the over position of all three channels simultaneously. In $\mathrm{L}_{4}$ ganglion $\mathrm{FB}^{+}$neurons $(\mathbf{a}, \mathbf{i})$ which were simultaneously $\mathrm{D}_{3} \mathrm{H}^{+}(\mathbf{b}, \mathbf{j})$ as well as $\mathrm{nNOS}^{+}(\mathbf{c})$ and $\mathrm{SP}^{+}(\mathbf{k})$. Visible one $\mathrm{FB}^{+}$ perikaryon (e) containing D $\beta \mathrm{H}(\mathbf{f})$ and $\operatorname{LENK}(\mathbf{g})$ in $\mathrm{S}_{1} \mathrm{SChG}$. In $\mathrm{L}_{6}$ ganglion $\mathrm{FB}^{+}$neurons $(\mathbf{m})$ which were simultaneously $\mathrm{D} \beta \mathrm{H}^{+}(\mathbf{n})$ as well as $\mathrm{GAL}^{+}(\mathbf{o})$. Scale bar $=50 \mu \mathrm{m}$.

Double-labeling immunohistochemistry revealed that the vast majority of the small- and large-sized skin-projecting SChG cells displayed immunoreactivity to $\mathrm{D} \beta \mathrm{H}$, indicating the 
catecholaminergic nature of these neurons. It is worth mentioning that the frequency of the small- and large-sized neurons containing this enzyme was similar in lumbar and sacral SChG (Table 3).

Table 3. Percentages of retrogradely labeled small- and large-sized neurons in the porcine lumbar $\left(\mathrm{L}_{4}-\mathrm{L}_{6}\right)$ and sacral $\left(\mathrm{S}_{1}-\mathrm{S}_{2}\right)$ sympathetic chine ganglia projecting to the skin of the hindlimb, which were simultaneously dopamine $\beta$-hydroxylase-positive $\left(\mathrm{D} \beta \mathrm{H}^{+}\right)$or -negative $\left(\mathrm{D} \beta \mathrm{H}^{-}\right)$.

\begin{tabular}{ccccccc}
\hline Size of the $\mathbf{F B}^{+}$Neurons & Marker & $\mathbf{L}_{\mathbf{4}}$ & $\mathbf{L}_{\mathbf{5}}$ & $\mathbf{L}_{\mathbf{6}}$ & $\mathbf{S}_{\mathbf{1}}$ & $\mathbf{S}_{\mathbf{2}}$ \\
\hline \multirow{2}{*}{ small } & $\mathrm{D} \beta \mathrm{H}^{+}$ & $86.1 \pm 6.6$ & $87.4 \pm 4.3$ & $85.0 \pm 6.2$ & $83.1 \pm 5.4$ & $84.0 \pm 4.5$ \\
& $\mathrm{D} \beta \mathrm{H}^{-}$ & $13.8 \pm 6.6$ & $12.5 \pm 4.3$ & $14.9 \pm 6.2$ & $16.8 \pm 5.4$ & $15.9 \pm 4.5$ \\
\hline \multirow{2}{*}{ large } & $\mathrm{D} \beta \mathrm{H}^{+}$ & $84.3 \pm 6.9$ & $75.1 \pm 15.5$ & $77.0 \pm 11.1$ & $84.2 \pm 17.9$ & $82.1 \pm 15.5$ \\
& $\mathrm{D} \beta \mathrm{H}^{-}$ & $15.6 \pm 6.9$ & $24.8 \pm 15.5$ & $22.9 \pm 11.1$ & $15.7 \pm 17.9$ & $17.8 \pm 15.5$ \\
\hline
\end{tabular}

Data were expressed as mean \pm standard error $( \pm$ SEM $)$.

Moreover, these neurons also showed positivity for all other markers tested (PACAP, SOM, NOS, SP, NPY, VIP, LENK and GAL) but their percentages vary depending on the size and the location alongside the spinal cord.

\subsubsection{Lumbar SChG}

Immunohistochemistry revealed that $\mathrm{FB}^{+} /{\mathrm{D} \beta \mathrm{H}^{+}}^{+}$small-sized cells stained for SOM, NPY and GAL were most numerous in $\mathrm{L}_{4}$, containing PACAP and LENK in $\mathrm{L}_{5}$, while the cells immunorective for $\mathrm{FB}^{+} / \mathrm{D} \beta \mathrm{H}^{+} / \mathrm{VIP}^{+}$(Figure $5 \mathrm{e}-\mathrm{h}$ ) and $\mathrm{FB}^{+} / \mathrm{D} \beta \mathrm{H}^{+} / \mathrm{SP}^{+}$in $\mathrm{L}_{6}$. In the

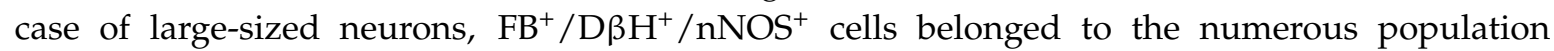

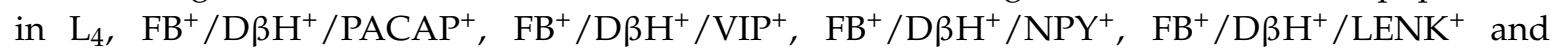

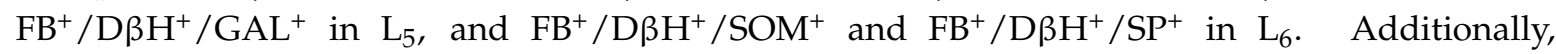
the percentage of $\mathrm{FB}^{+} / \mathrm{D} \beta \mathrm{H}^{+} / \mathrm{SOM}^{+}$and $\mathrm{FB}^{+} / \mathrm{D} \beta \mathrm{H}^{+} / \mathrm{NPY}^{+}$small-sized neurons decreased in the caudal direction. Detailed data on the neurochemical phenotypes characteristic of skin-projecting neurons in lumbar SChG are present in Table 1.

$\mathrm{L}_{4} \mathrm{SChG}$

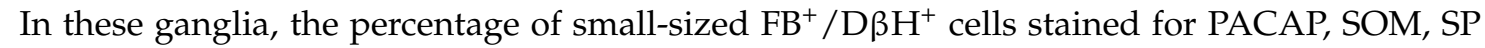
(Figure 6i-1), VIP or NPY was significantly higher when compared to the large-sized cells. In turn, in comparison to these cells, the percentage of small-sized $\mathrm{FB}^{+} / \mathrm{D} \beta \mathrm{H}^{+}$cells containing nNOS was lower (Figure 6a-d). Only a few of small- and large-sized $\mathrm{FB}^{+} /{\mathrm{D} \beta \mathrm{H}^{+}}^{+}$neurons also exhibited LENK, while the latter neurons were completely devoid of GAL.

\section{$\mathrm{L}_{5} \mathrm{SChG}$}

In these ganglia, the percentage of $\mathrm{FB}^{+} / \mathrm{D} \beta \mathrm{H}^{+}$small-sized cells exhibiting $\mathrm{nNOS}$ was higher than large-sized neurons. Double-labeling also revealed that the percentage of the $\mathrm{FB}^{+} / \mathrm{D} \beta \mathrm{H}^{+}$small-sized cells that co-localized with NPY, LENK and GAL was lower than large-sized neurons containing these markers. It is worth adding that no large-sized $\mathrm{FB}^{+} / \mathrm{D} \beta \mathrm{H}^{+}$cells were immunoreactive for SP. It was also found that the frequency of $\mathrm{FB}^{+} / \mathrm{D} \mathrm{H}^{+}$small- and large-sized cells exhibiting PACAP, SOM or VIP was similar in both studied populations.

$\mathrm{L}_{6} \mathrm{SChG}$

The percentage of $\mathrm{FB}^{+} / \mathrm{D} \beta \mathrm{H}^{+}$small-sized neurons also stained for nNOS, SP or VIP was higher when compared to large-sized cells. In addition, $\mathrm{FB}^{+} / \mathrm{D} \beta \mathrm{H}^{+}$large-sized neurons more often co-expressed SOM or NPY than small-sized neurons (NPY; Figure 5a-d). Differences in the percentages of small- and large-sized neurons containing $\mathrm{FB}^{+} / \mathrm{D} \beta \mathrm{H}^{+}$with PACAP, LENK or GAL (Figure 6m-p) were statistically insignificant. 


\subsubsection{Sacral SChG}

Double-labeling immunohistochemistry revealed that $\mathrm{FB}^{+} / \mathrm{D} \beta \mathrm{H}^{+}$small-sized cells co-expressed

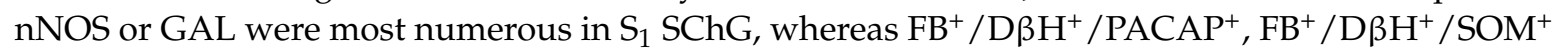
and $\mathrm{FB}^{+} / \mathrm{D} \beta \mathrm{H}^{+} / \mathrm{VIP}^{+}$were most numerous in $\mathrm{S}_{2} \mathrm{SChG}$. The $\mathrm{FB}^{+} / \mathrm{D} \beta \mathrm{H}^{+} / \mathrm{SOM}^{+}$and $\mathrm{FB}^{+} / \mathrm{D} \beta \mathrm{H}^{+} / \mathrm{VIP}^{+}$

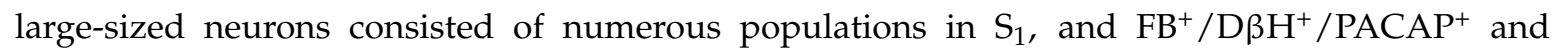

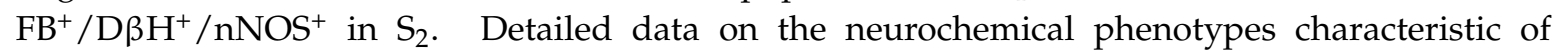
skin-projecting neurons in sacral SChG are present in Table 2.

\section{$\mathrm{S}_{1} \mathrm{SChG}$}

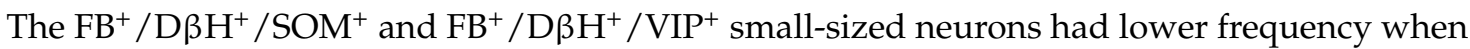
compared to the large-sized neurons. Additionally, the frequency of $\mathrm{FB}^{+} / \mathrm{D} \beta \mathrm{H}^{+} / \mathrm{NPY}^{+}$small- and large-sized cells was similar. It is worth adding that the $\mathrm{FB}^{+} / \mathrm{D} \beta \mathrm{H}^{+}$large-sized neurons were devoid of PACAP (small-sized FB ${ }^{+}$neurons; Figure 5i-l), nNOS, SP, LENK (small-sized FB ${ }^{+}$neurons; Figure 6e-h) and GAL.

\section{$\mathrm{S}_{2} \mathrm{SChG}$}

The percentage of $\mathrm{FB}^{+} / \mathrm{D} \beta \mathrm{H}^{+}$small-sized neurons that co-localized with PACAP, SOM (Figure $5 \mathrm{~m}-\mathrm{p}$ ) or VIP was higher when compared to large-sized neurons, whereas the frequency of $\mathrm{FB}^{+} / \mathrm{D} \mathrm{H}^{+} / \mathrm{nNOS}^{+}$small-sized cells was significantly lower than that observed in large-sized neurons. No $\mathrm{FB}^{+} / \mathrm{D} \beta \mathrm{H}^{+}$large-sized neurons co-localized with SP, NPY, LENK and GAL were found.

\section{Discussion}

This is the first report demonstrating both the distribution and neurochemical phenotyping of sympathetic neurons projecting to skin of the porcine hindlimb. The major source of sympathetic nerve fibers supplying this region originates from the $\mathrm{L}_{2}$ to $\mathrm{S}_{2} \mathrm{SChG}$. These results are consistent with the data obtained from humans [21] and cats [22]. Nevertheless, in humans, these neurons were present only in lumbar SChG, while in cats they were also present in sacral ganglia.

We have also found that in the porcine skin-projecting SChG neurons may be subdivided into two size-classes: small- and large-sized neurons. The percentage of small-sized neurons was significantly higher when compared to large-sized cells in all studied SChG ganglia. These findings correlate well with results reported by Chyczewski et al. [35] and Ragionieri et al. [36], although these authors studied the population of the SChG neurons projecting to the longissimus dorsi muscle and urinary bladder in pigs, respectively. As may be judged from their size (mainly small), neurons supplying skin of the porcine hidlimb are most probably vasoconstrictors, as postulated in pig [37] and guinea pig [38].

There are other interesting observations in terms of the distribution pattern of the porcine skin-innervating neurons within subdomains of the studied ganglia, defined by ganglion geometry (i.e., the arrangement of its longest and shortest axis). It has been found that small-sized neurons were primarily found in the caudo-dorsal subdomain of sacral SChG, whereas the majority of large-sized neurons were found in the cranio-dorsal subdomain of lumbar and sacral SChG. The somatotopic distribution of sympathetic innervating different organs in pig ganglia has been observed by several authors $[24,36,39,40]$. Moreover, a cranio-caudal somatotopic organization, in reference to skin-projecting dorsal root ganglia neurons supplying the porcine hindlimb, has previously been postulated by Kozłowska et al. [41].

The present study has disclosed that most of the FB-labeled sympathetic small- and large-sized neurons had a catecholaminergic nature, as revealed by immunoreactivity for $\mathrm{D} \beta \mathrm{H}$. These results correlate well with studies describing the adrenergic character of a substantial part of the SChG neurons in the pig [23-28,37]. Only a small percentage of skin-projecting sympathetic neurons were devoid of these enzymes, which may indicate that they are a population of non-adrenergic, possibly cholinergic neurons, which is congruent with earlier studies conducted in the pig [42,43]. 


\subsection{Dopamine $\beta$-Hydroxylase (D $\beta H)$ and/or Neuropeptide $Y$ (NPY)}

The present data indicate that a significant amount $\mathrm{D} \beta \mathrm{H}^{+}$small- and large-sized perikarya also expressed NPY immunoreactivity. NPY is found in cutaneous sympathetic neurons of rodents and in humans [44,45]. Moreover, the skin-projecting neurons exhibiting D $\beta H$ and NPY, in the present study, could be the predominant source of the D $\beta \mathrm{H} / \mathrm{NPY}$-immunorective (-IR) nerve fibers supplying skin blood vessels [46,47]. These neurons may cause vasoconstriction of these vessels, and in this way regulate blood flow through the skin $[8,48,49]$. Moreover, noradrenaline (NA) and NPY are unquestionably engaged in the modulation of cutaneous pain in humans [50-53]. Additionally, in the present study, the percentage of $\mathrm{FB}^{+} / \mathrm{D} \mathrm{H}^{+} / \mathrm{NPY}^{+}$small-sized neurons in the lumbar SChG decrease from the cranial to the caudal direction. It is plausible that these neurons, distributed with different frequencies in the lumbar SChG, can modulate skin functions at different levels. Several $\mathrm{FB}^{+} / \mathrm{NPY}^{+}$ small- and large-sized neurons innervating the porcine skin of the hindlimb were non-adrenergic. It is possible that this infrequent population of neurons could act in dependently of NA to induce vasoconstriction, which was previously reported by Stephens et al. [30] in humans during whole body cooling. However, the exact function of non- adrenergic $\mathrm{FB}^{+} / \mathrm{NPY}^{+}$skin-projecting neurons in pigs remains unexplained and requires further investigation.

\section{2. $D \beta H$ and/or Somatostatin (SOM)}

The moderate number of $\mathrm{FB}^{+} / \mathrm{D} \beta \mathrm{H}^{+}$small- and large-sized SChG neurons was found to stain SOM. SOM has been previously found co-expressed of NA markers in neurons of the porcine SChG supplying the mammary gland [54], urinary bladder [26,27] and ovary [23]. A small proportion of FB+ small-sized neurons immunoreactive for SOM were non-adrenergic. It is worth adding that in this study the percentage of $\mathrm{FB}^{+} / \mathrm{D} \beta \mathrm{H}^{+} / \mathrm{SOM}^{+}$small-sized neurons in the lumbar sympathetic ganglia also decrease from the cranial to the caudal direction.

The SOM-IR nerve fibers have been found in the epidermis, dermis and, rarely, around blood vessels, sweat glands and hair follicles in human $[55,56]$. It should be pointed out that there is a lack of data concerning the biological function of SOM, released from nerve endings innervating skin of the hindlimb. However, it was reported that this peptide released from the stimulated sensory nerve terminals of rat sciatic nerve mediates the anti-inflammatory effect, and its receptors may play an important role in the tonic control of peripheral cutaneous nociceptors $[57,58]$. However, it is hard to

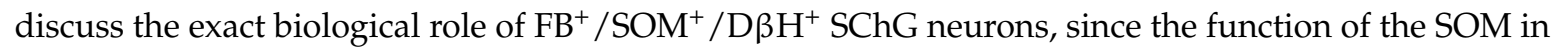
connection with NA in skin has also not yet been specified.

\section{3. $D \beta H$ and/or Neuronal Nitric Oxide Synthase (nNOS)}

$\mathrm{D} \beta \mathrm{H}$ and nNOS were co-expressed in an insignificant percentage of small- and large-sized skin-projecting neurons. The presence of nNOS with $\mathrm{D} \beta \mathrm{H}$ had earlier been observed in some SChG neurons projecting to the colon $[24,25]$, urinary bladder $[26,27]$ and to the extrinsic penile smooth musculature [59] of the pig. In the present study, a few small-sized non-adrenergic skin-projecting neurons $\left(\mathrm{L}_{6}\right.$ and $\left.\mathrm{S}_{2}\right)$ were nNOS-IR. The results presented by us may explain the origin of part of the nNOS-IR terminals around microvessels and the glandular duct observed by Ibba-Manneschi et al. [60] in human skin. It is generally known that nNOS is an indicator of nitric oxide (NO), which is component of cutaneous active vasodilation in humans [61]. Whereas, the distribution of $\mathrm{nNOS}$ with $\mathrm{D} \beta \mathrm{H}$ in the skin-projecting SChG neurons may implicate the involvement of endogenous NO and NA contributing to the temperature threshold of the axon reflex response to gradual local heating of skin, which was earlier observed in humans [62].

\section{4. $D \beta H$ and/or Substance (SP)}

These data revealed that a moderate percentage of adrenergic skin-projecting neurons also contained SP. These co-localizations have been found in the sympathetic neurons projecting to the 
muscle of the porcine genital tract $[59,63,64]$ and urinary bladder trigone [37]. Whereas $\mathrm{D} \beta \mathrm{H}^{+} / \mathrm{SP}^{+}$ nerve fibers have been found in monkey and rat lower lip skin supplying small arteries, veins and arterioles [5]. In the present study, the presence of SP in non- adrenergic small-sized skin-projecting neurons was only observed in $\mathrm{L}_{6} \mathrm{SChG}$. This finding is similar to that observed by Botti et al. [59], where the SP-IR SChG neurons projected to one pig retractor penis muscle. In adrenergic neurons, SP probably performs an inhibitory role on the action of NA, which was previously observed in mouse spinal cord [65]. Moreover, this peptide observed by us in $\mathrm{FB}^{+}$neurons with $\mathrm{D} \beta \mathrm{H}$ and alone may partially mediate cutaneous vasodilation through NO-dependent mechanisms [66].

\subsection{D $\beta H$ and/or Vasoactive Intestinal Peptide (VIP)}

The present results indicate that a part of $\mathrm{FB}^{+} / \mathrm{D} \beta \mathrm{H}^{+}$small- and large-sized SChG neurons has been found co-localized with VIP. This kind of co-localization was earlier observed in neurons of porcine SChG [67] projecting to the mammary gland [54], urinary bladder [26,27] and extrinsic penile smooth musculature [59]. Moreover, in the present work, VIP was also present sporadically in the non-adrenergic small-sized neurons (only in the sacral SChG) supplying skin of the porcine hindlimb, which could be a marker of cholinergic sympathetic neurons [68,69]. It was earlier reported that cutaneous VIP-IR nerve fibers supply dermal vessels, Merkel cells, hair follicles, as well as sweat, apocrine and Meibominan glands [70,71]. Based on literature data, it can be assumed that adrenergic and non-adrenergic skin-projecting neurons found in the present study may play an important role in the physiology of skin, including the regulation of blood vessels vasodilatation [72,73].

\section{6. $D \beta H$ and/or Leu5-Enkephalin (LENK)}

This study showed that adrenergic small- and large-sized (only in the lumbar SChG) skin-supplying neurons sporadically co-localized with LENK. This population of neurons had already been found in porcine SChG $[26,27,59]$. Furthermore, in the present study, some $\mathrm{FB}^{+}$small-sized neurons immunoreactive for LENK were non-adrenergic and observed only in $S_{1}$. It seems possible that, as observed by us, adrenergic and non-adrenergic neurons are a source of very rare nerve fibers in the skin, and may decrease the release of NA and, secondarily, blood pressure, as can be seen from pharmacological studies $[74,75]$. The second hypothesis can be partially confirm by our data, obtained from gilts used in the current study, which showed that nerve fibers containing LENK were found in the dermis around blood vessels (Kozłowska et al., unpublished observations). However, further studies are necessary to obtain confirmation of this hypothesis.

\section{7. $D \beta H$ and/or Cyclase-Activating Polypeptide (PACAP)}

$\mathrm{D} \beta \mathrm{H}$ and PACAP were co-localized in considerable percentages within the skin-projecting SChG small- and large-sized neurons. The co-localization of these substances had already been found in the nerve fibers inside the hypothalamus of rats [76]. Moreover, in the present study some small- and large-sized $\mathrm{FB}^{+}$immunoreactive for PACAP innervating porcine skin of the hindlimb were non-adrenergic. It is possible that skin-projecting SChG neurons might be the source of the $\mathrm{D} \beta \mathrm{H}^{+} / \mathrm{PACAP}^{+}$nerve fibers observed by Steinhoff et al. [77] close to the dermal-epidermal border, hair follicles, blood vessels and sweat glands in humans. Literature data suggest that PACAP is a vasodilatator and extravasation in the skin $[78,79]$. Thus, as may be judged from the above-mentioned data, PACAP with NA or alone may have a potent modulatory function in the skin's cutaneous blood flow. However, the exact physiological role of $\mathrm{D} \mathrm{H}^{+} / \mathrm{PACAP}^{+}$neurons in the functioning of skin of the hindlimb is still unknown.

\section{8. $D \beta H$ and/or $G A L$}

This study revealed that $\mathrm{FB}^{+} / \mathrm{D} \beta \mathrm{H}^{+} / \mathrm{GAL}^{+}$small- and large-sized neurons represent a portion of the retrogradely labeled cells. Additionally, the population of skin-projecting neurons was completely devoid of non-adrenergic GAL-IR cells. The co-existence of these substances was previously observed 
in SChG supplying the ovary [23]. The immunohistochemical study in humans demonstrated that GAL-IR nerve fibers in the skin were distributed around eccrine sweat glands, apocrine glands and blood vessels $[80,81]$. It was also reported that receptor 3 for the GAL was associated with dermal blood vessels, which suggests a role for this peptide in the regulation of microvasculature in skin [82]. This suggestion can be confirmed via a reduction of cutaneous plasma extravasationin GAL-overexpressing mice after activation of neurogenic inflammation [83]. Additionally, GAL may participate in nociceptive transmission, which was noted in mice [84].

In conclusion, the present study provides for the first time a detailed description of both the source of sympathetic nerve fibers innervating the skin of the porcine hindlimb and chemical phenotyping of neurons being the source of these fibers. Moreover, the differences observed by us between the studied ganglia in the percentage of D $\beta \mathrm{H}-\mathrm{IR}$ neurons co-localized with NPY, PACAP, VIP, SOM, nNOS, LENK, SP or GAL, suggest that these cells may play a role of modulators of sympathetic control at varying levels of skin function in pigs. Further research should be carried out to elucidate in detail the physiological relevance of each subpopulation of neurons innervating skin of the porcine hindlimb.

\section{Materials and Methods}

\subsection{Laboratory Animals}

The experiment was performed on 4 juvenile female crossbred gilts (Pietrain $\times$ Duroc), aged 8-12 weeks and weighting $15-20 \mathrm{~kg}$. All animals were housed and treated in accordance with the Principles of Laboratory Animal Care (NIH publication no. 86-23, revised 1985). All experimental procedures were approved by the Local Ethical Commission of the University of Warmia and Mazury in Olsztyn (No. 36/2013). Seven days before surgical operations the animals were transported from a farm to the local animal house, where they were individually housed in stalls, under conditions of natural light and room temperature. All animals were fed with a commercial grain mixture (Grower Plus, Wipasz, Wadag, Poland), and they had free access to water. $24 \mathrm{~h}$ before surgery feeding was stopped. All efforts were made to minimize the number of animals used and their suffering.

\subsection{Anesthesia, Surgery and Tissue Processing}

Thirty minutes before the main anesthetic was given, the animals were pretreated with atropine sulfate (Polfa, Warsaw, Poland; $0.04 \mathrm{mg} / \mathrm{kg}$ b.w., s.c.) and azaperone (Stressnil, Janssen Pharmaceutica, $\mathrm{NV}$, Beerse, Belgium; $0.5 \mathrm{mg} / \mathrm{kg}$ b.w., i.m). All animals were anesthetized with sodium thiobarbital (Thiopenthal, Sandoz, Holzkirchen, Germany; $20 \mathrm{mg} / \mathrm{kg}$ b.w., i.v., inafractionate dinfusion). After induction of the surgical anesthesia, the skin of the left hindlimb was gently shaved, disinfected with $1 \%$ water-alcoholic solution of iodinetincture, and then a total volume of $100 \mu \mathrm{L}$ of $5 \%$ aqueous solution of the fluorescent retrograde tracer Fast Blue (FB; EMS-Chemie GmbH, Groß-Umstadt, Hesse, Germany) was administered in multiple injections in to the external surface of the skin using a Hamilton microsyringe equipped with a $26 \mathrm{~S}$ gauge needle. Injections were made at equal intervals of one centimeter, and they strictly covered the skin area innervated by cutaneous branches of the femoral and sciatic nerves $(100 \mu \mathrm{L})$ [41]. Four weeks later all the animals were euthanized by an overdose of sodium thiobarbital and, after cessation of breathing and heart beating, transcardially perfused with $4 \%$ buffered paraformaldehyde ( $\mathrm{pH} 7.4)$. Bilateral SChG $\left(\mathrm{Th}_{12}-\mathrm{S}_{4}\right)$ were collected from all animals studied and then postfixed by immersion in the same fixative for $15 \mathrm{~min}$, washed twice in $0.1 \mathrm{M}$ phosphate buffer $\left(\mathrm{pH} 7.4,4^{\circ} \mathrm{C}\right)$ for over three days, and then stored in $18 \%$ buffered sucrose solution containing $0.01 \%$ sodium azide ( $\mathrm{pH} 7.4$ ) at $4{ }^{\circ} \mathrm{C}$ until they sank. Finally, the tissues were frozen and then coronally sectioned at a thickness of $10 \mu \mathrm{m}$ using a cryostat (HM525 Zeiss, Jena, Germany). The sections were stored at $-80^{\circ} \mathrm{C}$ until further processing. 


\subsection{Immunofluorescence Procedures}

The sections were processed for routine double-immunofluorescence labeling using primary antisera, raised in different species and species-specific secondary antibodies listed in Table 4.

Table 4. Primary antisera, secondary reagents and dilutions used in the study $(\mathrm{D} \beta \mathrm{H}$, dopamine- $\beta$-hydroxylase; NPY, neuropeptide Y; VIP, vasoactive intestinal polypeptide; PACAP, pituitary adenylate cyclase-activating polypeptide, SOM, somatostatin; $\mathrm{nNOS}$, neuronal nitric oxide synthase; LENK, leu5-enkephalin; SP, substance P; GAL, galanin; and FITC, fluorescein isothiocyanate).

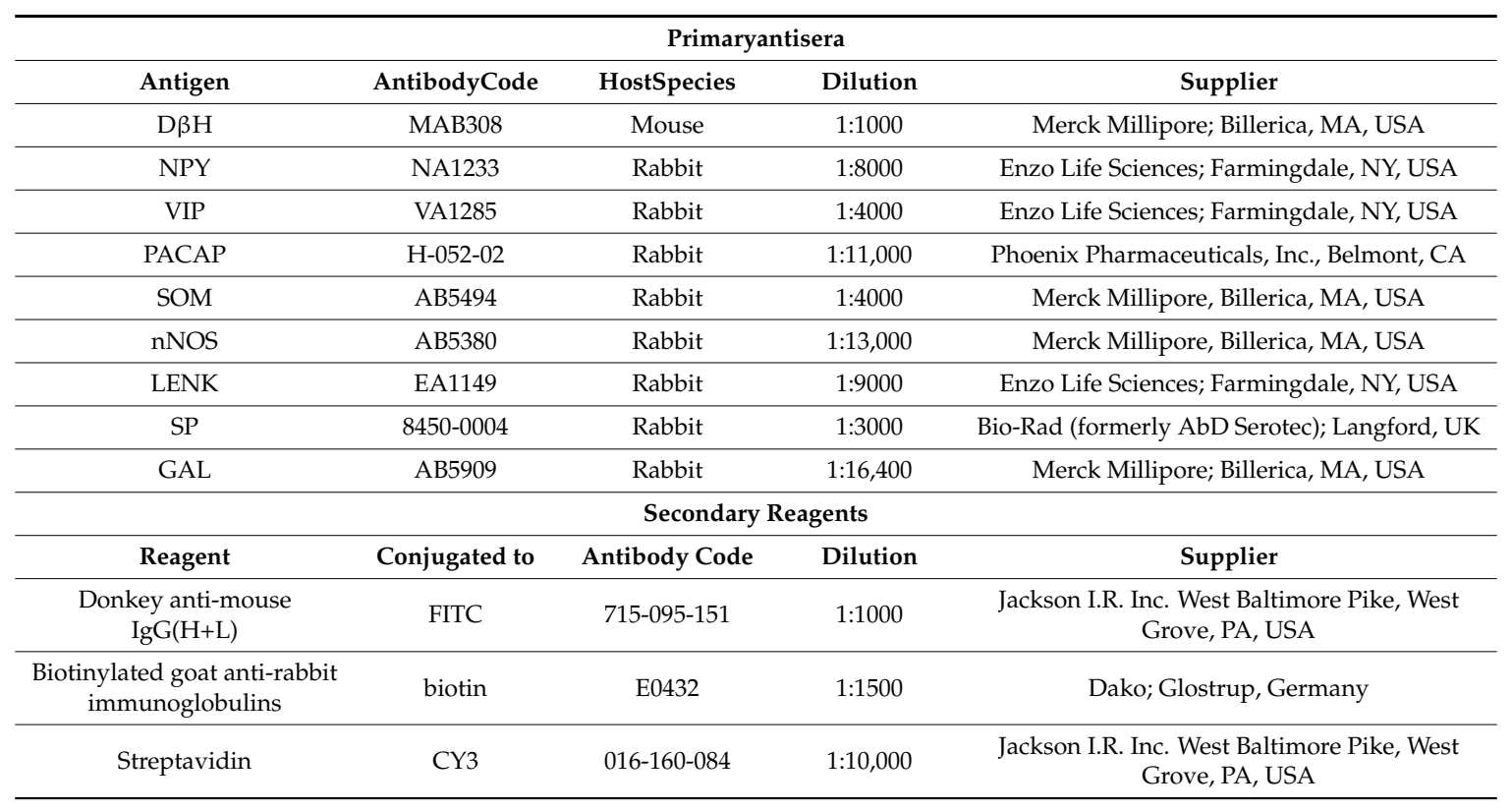

Immunohistochemistry involved double-staining, which was applied to sections from $\mathrm{L}_{4}-\mathrm{L}_{6}, \mathrm{~S}_{1}$ and $S_{2}$ ganglia. The sections were selected from three different representative regions of the ganglia (upperone-third, middle and lower one-third).

Due to the presence of FB+ neurons in the studied sections, all steps of the procedures described below were performed in darkness. Thus, sections were air-dried at room temperature (RT) for $45 \mathrm{~min}$, rinsed three times in phosphate-buffered saline (PBS, pH 7.4), and then, in order to block all the unspecific binding sites, incubated for $1 \mathrm{~h}$ in a humid chamber with a blocking solution containing 1\% Triton X-100 (Sigma-Aldrich, St. Louis, MO, USA), 0.1\% bovine serum albumin (Sigma-Aldrich, St. Louis, MO, USA), 0.05\% thimerosal (Sigma-Aldrich, St. Louis, MO, USA), 0.01\% $\mathrm{NaN}_{3}$ (POCH, Gliwice, Poland) and 10\% normal goat serum (Jackson Immunoresearch, West Grove, PA, USA) in 0.01 M PBS.

For the double-labeling immunofluorescence, a mixture of two primary antibodies was used. After the incubation with primary antibodies, sections were rinsed in PBS $(3 \times 15 \mathrm{~min})$ and incubated for $1 \mathrm{~h}$ with a mixture of appropriate FITC-conjugated secondary antisera and biotinylated donkey anti-rabbit antibodies. The latter antibodies were finally visualized by additional incubation of sections with streptavidin-CY3 complex for 1 h. Following subsequent rinsing in PBS $(3 \times 15 \mathrm{~min})$, the sections were coverslipped with carbonate-buffered glycerol ( $\mathrm{pH} 8.6)$.

\subsection{Counting of Neurons and Statistical Analysis}

The sections were viewed under an Olympus BX61 microscope (Shinjuku, Tokyo, Japan) equipped with epi-fluorescence and appropriate, small-band filter sets for FB, FITC and CY3. Images were acquired by a PC equipped with a CCD camera operated by CellSens Dimension image analyzing software (Olympus, Warszawa, Poland). 
To avoid a double-counting of labeled neurons, only FB-positive perikary a with a clearly visible nucleus were counted in each fourth section of the particular SChG studied. Moreover, to further unravel the intraganglionic distribution of FB-traced neurons, each of the SChG sections of interest was divided, along their long and short axes, into four subdomains: cranio-dorsal, cranio-ventral, caudo-dorsal and caudo-ventral (Figure 7).

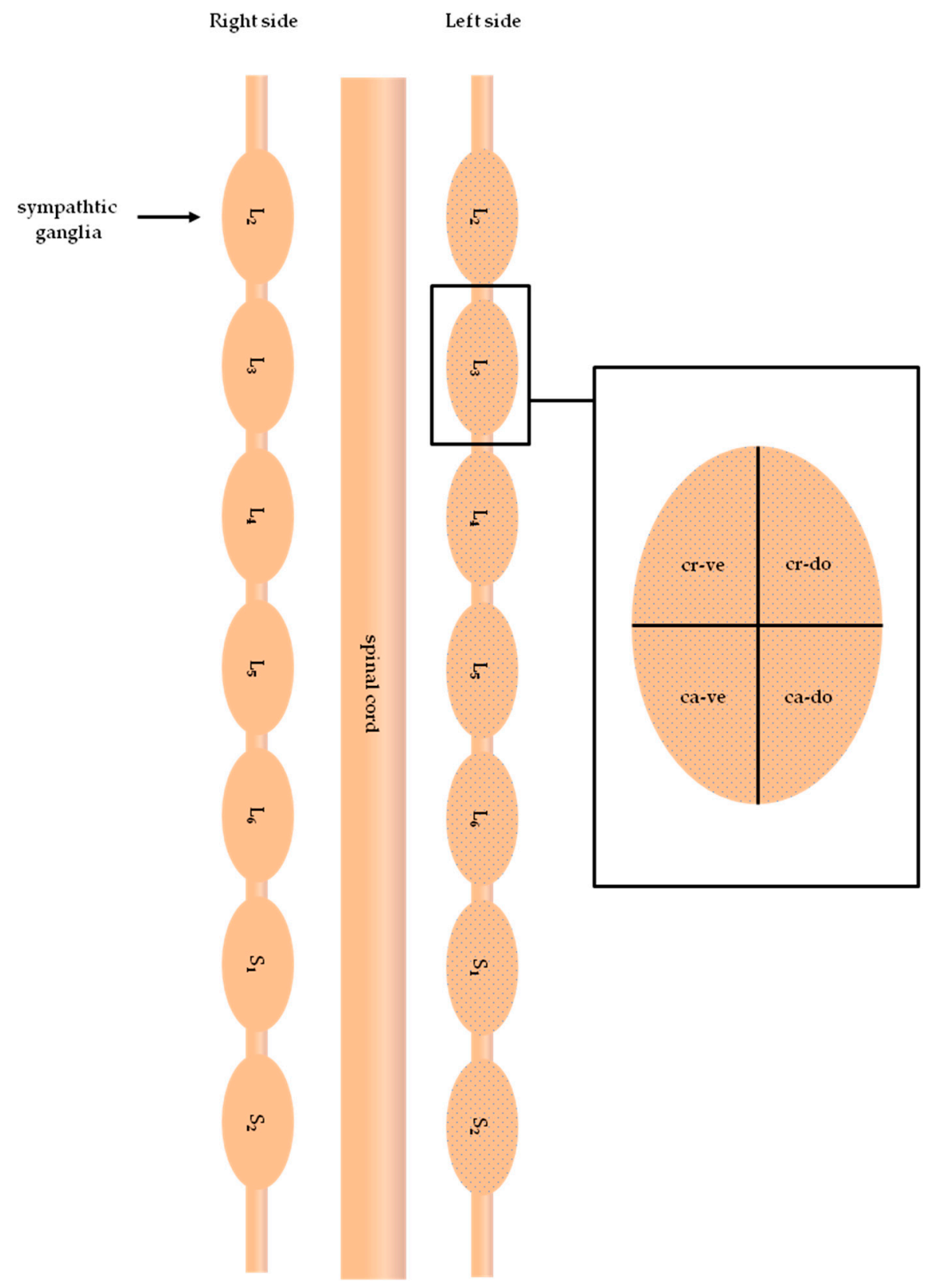

Figure 7. A schematic diagram of sympathetic chain ganglia (SChG) showing topographical subdomains in which the relative frequencies of skin projecting neurons were counted. cr-do, cranio-dorsal; cr-ve, cranio-ventral; ca-do, caudo-dorsal; and ca-ve, caudo-ventral subdomains of the SChG.

The perikarya were divided into two subclasses according to diameter: small $(<25 \mu \mathrm{m}$ in diameter; mean $17.4 \pm 6.0)$ and large $(>25 \mu \mathrm{m}$ in diameter; mean $29.6 \pm 5.4$; Figure 8$)$. Their size was measured using CellSens Dimension image analyzing software. 


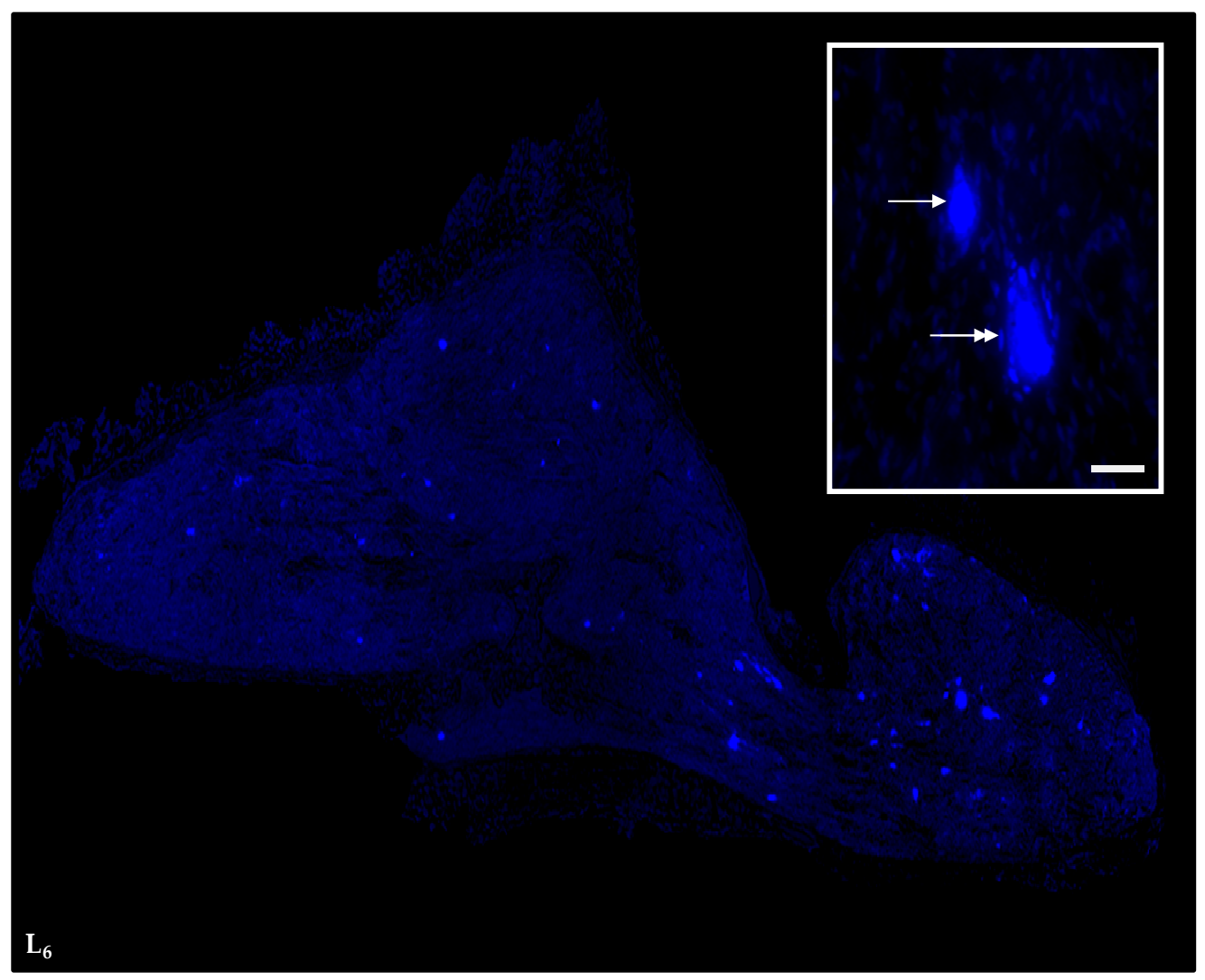

Figure 8. Consecutive microphotographs-based reconstruction of a paramedian section of the $\mathrm{L}_{6}$ SChG demonstrating intraganglionic distribution pattern of retrogradely-labeled small- $(<25 \mu \mathrm{m})$ and large-sized $(>25 \mu \mathrm{m})$ skin-projecting neurons. Insert: a fragment of a microphotograph made at a "working" magnification used for morphometric analysis of retrogradely-labeled perikarya; a typical small-sized neuron is indicated by an arrow, while a double-headed arrow points out to a large-sized cell. Scale bar in insert $=50 \mu \mathrm{m}$.

$\mathrm{FB}+$ neurons were counted with in individual lumbar and sacral SChG, as well as within each of the ganglionic subdomains. These counts were expressed as the percentages of small- and large-sized $\mathrm{FB}^{+}$neurons in each of the SChG or ganglionic subdomains, always considering the total number of $\mathrm{FB}^{+}$neurons as $100 \%$ within each the studied segment or ganglionic subdomains. A similar paradigm was used to evaluate the inter- as well as intra-ganglionic distribution patterns of the double-immunolabeled neurons. However, the relative frequencies of neurons within ganglionic subdomains were calculated from the pooled values of FB-labeled neurons in lumbar SChG $\left(\mathrm{L}_{4}-\mathrm{L}_{6}\right)$ and sacral SChG $\left(\mathrm{S}_{1}\right.$ and $\left.\mathrm{S}_{2}\right)$.

Data concerning the segmental distribution and the number of skin-projecting sympathetic perikarya in the total population of lumbar and sacral SChG were analyzed using the Mann-Whitney $U$-test. The statistical importance of differences found between ganglia of data was analyzed using one-way ANOVA followed by the Tukey test using GraphPad Prism4 software (GraphPad Software, LaJolla, CA, USA). Differences between population small- and large-sized neurons innervating skin of the hindlimb were compared using the Mann-Whitney $U$-test. $p<0.05$ was considered to be statistically significant.

\subsection{Specificity Tests of Tracing and Labeling Procedures}

After a careful examination of each injection site, traces of FB were found neither in muscles, nor in the subcutaneous tissues in the vicinity of the tracer deposition places. The specificity of primary 
or secondary antisera was tested by: (1) preabsorption tests based on incubation with an antibody that had been preabsorbed with synthetic antigen $(25 \mu \mathrm{g}$ of appropriate antigen per $1 \mathrm{~mL}$ of corresponding antibody at working dilution); and (2) omission and replacement tests during which the primary or secondary antibody was omitted or replaced by non-immune sera or PBS. Lack of any visible fluorescence indicated the specificity of the labeling.

\section{Conclusions}

In conclusion, the present study provides for the first time a detailed description of both the source of sympathetic nerve fibers innervating the skin of the porcine hindlimb and chemical phenotyping of neurons being the source of these fibers. Moreover, the differences observed by us between the studied ganglia in the percentage of D $\beta \mathrm{H}-\mathrm{IR}$ neurons co-localized with NPY, PACAP, VIP, SOM, nNOS, LENK, SP or GAL suggest that these cells may play a role of modulators of sympathetic control at varying levels of skin function in pigs. Further research should be carried out to elucidate in detail the physiological relevance of each subpopulation of neurons innervating skin of the porcine hindlimb.

Acknowledgments: This study was supported by the statutory grant No. 25.610.001-300, Faculty of Medical Sciences, the University of Warmia and Mazury in Olsztyn, Poland.

Author Contributions: Anna Kozłowska conceived and designed the experiments; Anna Kozłowska, Anita Mikołajczyk and Mariusz Majewski performed the experimental procedures; and Anna Kozłowska performed the immunohistochemical procedures, analyzed the data and wrote the paper.

Conflicts of Interest: The authors declare no conflict of interest.

\section{References}

1. Brain, S.D.; Moore, P.K. Pain and neurogenic inflammation. In Progress in Inflammation Research; Springer: Basel, Switzerland, 1999.

2. Björklund, H.; Dalsgaard, C.J.; Jonsson, C.E.; Hermansson, A. Sensory and autonomic innervation of non-hairy and hairy human skin. An immunohistochemical study. Cell Tissue Res. 1986, 243, 51-57. [CrossRef] [PubMed]

3. Karanth, S.S.; Springall, D.R.; Kuhn, D.M.; Levene, M.M.; Polak, J.M. An immunocytochemical study of cutaneous innervation and the distribution of neuropeptides and protein gene product 9.5 in man and commonly employed laboratory animals. Am. J. Anat. 1991, 191, 369-383. [CrossRef] [PubMed]

4. Debeer, S.; Le Luduec, J.B.; Kaiserlian, D.; Laurent, P.; Nicolas, J.F.; Dubois, B.; Kanitakis, J. Comparative histology and immunohistochemistry of porcine versus human skin. Eur. J. Dermatol. 2013, 23, 456-466. [CrossRef] [PubMed]

5. Ruocco, I.; Cuello, A.C.; Parent, A.; Ribeiro-da-Silva, A. Skin blood vessels are simultaneously innervated by sensory, sympathetic, and parasympathetic fibers. J Comp. Neurol. 2002, 448, 323-336. [CrossRef] [PubMed]

6. Roth, S.; Kummer, W. A quantitative ultrastructural investigation of tyrosine hydroxylase-immunoreactive axons in the hairy skin of the guinea pig. Anat. Embryol. 1994, 190, 155-162. [CrossRef] [PubMed]

7. Jänig, W.; Kümmel, H. Organization of the sympathetic innervation supplying the hairless skin of the cat's paw. J. Auton. Nerv. Syst. 1981, 3, 215-230. [CrossRef]

8. Morris, J.L. Cotransmission from sympathetic vasoconstrictor neurons to small cutaneous arteries in vivo. Am. J. Physiol. 1999, 277, H58-H64. [PubMed]

9. Mark, A.L.; Abboud, F.M.; Schmid, P.G.; Heistad, D.D.; Mayer, H.E. Differences in direct effects of adrenergic stimuli on coronary, cutaneous, and muscular vessels. J. Clin. Investig. 1972, 51, 279-287. [CrossRef] [PubMed]

10. Vetrugno, R.; Liguori, R.; Cortelli, P.; Montagna, P. Sympathetic skin response: Basic mechanisms and clinical applications. Clin. Auton. Res. 2003, 13, 256-270. [CrossRef] [PubMed]

11. Charkoudian, N. Skin blood flow in adult human thermoregulation: How it works, when it does not, and why. Mayo Clin. Proc. 2003, 78, 603-612. [CrossRef] [PubMed]

12. Brengelmann, G.L.; Savage, M.V. Temperature regulation in the neutral zone. Ann. N. Y. Acad. Sci. 1997, 813, 39-50. [CrossRef] [PubMed] 
13. Rowell, L.B. Reflex control of the cutaneous vasculature. J. Investig. Dermatol. 1977, 69, 154-166. [CrossRef] [PubMed]

14. Lindblad, L.E.; Ekenvall, L. $\alpha$-adrenoceptors in the vessels of human finger skin. Acta. Physiol. Scand. 1986, 128, 219-222. [CrossRef] [PubMed]

15. Kenney, W.L. Effects of Selective $\alpha$-Adrenergic Blockade on Control of Human Skin Blood Flow during Exercise. In Temperature Regulation; Part of the Series Advances in Pharmacological Sciences; Milton, A.C., Ed.; Springer: Basel, Switzerland, 1994; pp. 151-157.

16. Stephens, D.P.; Aoki, K.; Kosiba, W.A.; Johnson, J.M. Nonnoradrenergic mechanism of reflex cutaneous vasoconstriction in men. Am. J. Physiol. Heart Circ. Physiol. 2001, 280, H1496-H1504. [PubMed]

17. Mizuno, S.; Takebayashi, T.; Kirita, T.; Tanimoto, K.; Tohse, N.; Yamashita, T. The effects of the sympathetic nerves on lumbar radicular pain: A behavioural and immunohistochemical study. Mayo Clin. Proc. 2007, 78, 603-612. [CrossRef] [PubMed]

18. Iwase, T.; Takebayashi, T.; Tanimoto, K.; Terashima, Y.; Miyakawa, T.; Kobayashi, T.; Tohse, N.; Yamashita, T. Sympathectomy attenuates excitability of dorsal root ganglion neurons and pain behaviour in a lumbar radiculopathy model. Bone Jt. Res. 2012, 1, 198-204. [CrossRef] [PubMed]

19. Bridges, D.; Thompson, S.W.; Rice, A.S. Mechanisms of neuropathic pain. Br. J. Anaesth. 2001, 87, 12-26. [CrossRef] [PubMed]

20. Nascimento, F.P.; Magnussen, C.; Yousefpour, N.; Ribeiro-da-Silva, A. Sympathetic fibre sprouting in the skin contributes to pain-related behaviour in spared nerve injury and cuff models of neuropathic pain. Mol. Pain 2015, 11. [CrossRef] [PubMed]

21. Svoboda, R.M.; Cronenwett, J.L. Lumbar sympathectomy for lower extremity ischemic ulcers. In Therapy in Vascular and Endovascular Surgery, 5th ed.; Stanley, J.C., Veith, F.J., Wakefield, T.W., Eds.; Elsevier Inc.: Amsterdam, The Netherlands, 2014; p. 612.

22. Lindh, B.; Lundberg, J.M.; Hökfelt, T. NPY-, galanin-, VIP/PHI-, CGRP- and substance P-immunoreactive neuronal subpopulations in cat autonomic and sensory ganglia and their projections. Cell Tissue Res. 1989, 256, 259-273. [CrossRef] [PubMed]

23. Koszykowska, M.; Całka, J.; Gańko, M.; Jana, B. Long-term estradiol-17 $\beta$ administration reduces population of neurons in the sympathetic chain ganglia supplying the ovary in adult gilts. Exp. Mol. Pathol. 2011, 91, 353-361. [CrossRef] [PubMed]

24. Skobowiat, C.; Calka, J.; Wasowicz, K.; Majewski, M. Distribution pattern and chemical coding of neurons of the sympathetic chain ganglia supplying the descending colon in the pig. Acta Vet. Hung. 2010, 58, 189-198. [CrossRef] [PubMed]

25. Skobowiat, C.; Gonkowski, S.; Calka, J. Phenotyping of sympathetic chain ganglia (SChG) neurons in porcine colitis. J. Vet. Med. Sci. 2010, 72, 1269-1274. [CrossRef] [PubMed]

26. Lepiarczyk, E.; Bossowska, A.; Majewski, M. Changes in chemical coding of sympathetic chain ganglia (SChG) neurons supplying porcine urinary bladder after botulinum toxin (BTX) treatment. Cell Tissue Res. 2015, 360, 263-272. [CrossRef] [PubMed]

27. Lepiarczyk, E.; Majewski, M.; Bossowska, A. The influence of intravesical administration of resiniferatoxin (RTX) on the chemical coding of sympathetic chain ganglia (SChG) neurons supplying the porcine urinary bladder. Histochem. Cell Biol. 2015, 144, 479-489. [CrossRef] [PubMed]

28. Zalecki, M. Localization and neurochemical characteristics of the extrinsic sympathetic neurons projecting to the pylorus in the domestic pig. J. Chem. Neuroanat. 2012, 43, 1-13. [CrossRef] [PubMed]

29. Mundinger, T.O.; Verchere, C.B.; Baskin, D.G.; Boyle, M.R.; Kowalyk, S.; Taborsky, G.J., Jr. Galanin is localized in sympathetic neurons of the dog liver. Am. J. Physiol. 1997, 273, E1194-E1202. [PubMed]

30. Stephens, D.P.; Saad, A.; Bennett, L.A.; Kosiba, W.A.; Johnson, J.M. Neuropeptide Y antagonism reduces reflex cutaneous vasoconstriction in humans. Am. J. Physiol. Heart Circ. Physiol. 2004, 287, H1401-H1409. [CrossRef] [PubMed]

31. Shastry, S.; Dietz, N.M.; Halliwill, J.R.; Reed, A.S.; Joyner, M.J. Effects of nitric oxide synthase inhibition on cutaneous vasodilation during body heating in humans. J. Appl. Physiol. 1998, 85, 830-834. [PubMed]

32. Avon, S.L.; Wood, R.E. Porcine skin as an in vivo model for ageing of human bite marks. J. Forensic Odonto. Stomatol. 2005, 23, 30-39.

33. Jaggi, A.S.; Jain, V.; Singh, N. Animal models of neuropathic pain. Fundam. Clin. Pharmacol. 2011, 25, 1-28. [CrossRef] [PubMed] 
34. Herron, A.J. Pigs as Dermatologic Models of Human Skin Disease. In Proceedings of the ACVP/ASVCP Concurrent Annual Meetings, Monterey, CA, USA, 5-9 December 2009; pp. 5-9.

35. Chyczewski, M.; Wojtkiewicz, J.; Bossowska, A.; Jałyński, M.; Brzeski, W.; Kowalski, I.M.; Majewski, M. Sources of porcine longissimus dorsi muscle (LDM) innervation as revealed by retrograde neuronal tract-tracing. Folia Histochem. Cytobiol. 2006, 44, 189-194. [PubMed]

36. Ragionieri, L.; Botti, M.; Gazza, F.; Sorteni, C.; Chiocchetti, R.; Clavenzani, P.; Minelli, L.B.; Panu, R. Localization of peripheral autonomic neurons innervating the boar urinary bladder trigone and neurochemical features of the sympathetic component. Eur. J. Histochem. 2013, 57, e16. [CrossRef] [PubMed]

37. Majewski, M. Synaptogenesis and structure of the autonomic ganglia. Folia Morphol. 1999, 58, 65-99.

38. Gibbins, I.L.; Morris, J.L. Pathway specific expression of neuropeptides and autonomic control of the vasculature. Regul. Pept. 2000, 93, 93-107. [CrossRef]

39. Kaleczyc, J.; Timmermans, J.P.; Majewski, M.; Lakomy, M.; Scheuermann, D.W. Distribution and immunohistochemical characteristics of neurons in the porcine caudal mesenteric ganglion projecting to the vas deferens and seminal vesicle. Cell Tissue Res. 1995, 282, 59-68. [CrossRef] [PubMed]

40. Pidsudko, Z.; Kaleczyc, J.; Majewski, M.; Lakomy, M.; Scheuermann, D.W.; Timmermans, J.P. Differences in the distribution and chemical coding between neurons in the inferior mesenteric ganglion supplying the colon and rectum in the pig. Cell Tissue Res. 2001, 303, 147-158. [CrossRef] [PubMed]

41. Kozłowska, A.; Mikołajczyk, A.; Adamiak, Z.; Majewski, M. Distribution and chemical coding of sensory neurons innervating the skin of the porcine hindlimb. Neuropeptides 2016, 61, 1-14. [CrossRef] [PubMed]

42. Łakomy, M.; Happola, O.; Majewski, M.; Wassowicz, K. Neuropeptides in the porcine coeliac-superior mesenteric ganglion. Folia Histochem. Cytobiol. 1993, 31, 181-191. [PubMed]

43. Pidsudko, Z. Immunohistochemical characteristics and distribution of neurons in the paravertebral, prevertebral and pelvic ganglia supplying the urinary bladder in the male pig. J. Mol. Neurosci. 2014, 52, 56-70. [CrossRef] [PubMed]

44. Gibbins, I.L. Autonomic pathways to cutaneous effectors. In Autonomic Innervation of Skin; Morris, J.L., Gibbins, I.L., Eds.; Harwood Academie Publishers: Amsterdam, The Netherlands, 1997; p. 56.

45. Gibbins, I.L.; Morris, J.L. Sympathetic noradrenergic neurons containing dynorphin but not neuropeptide $Y$ innervate small cutaneous blood vessels of guinea-pigs. J. Auton. Nerv. Syst. 1990, 29, 137-149. [CrossRef]

46. Roosterman, D.; Goerge, T.; Schneider, S.W.; Bunnett, N.W.; Steinhoff, M. Neuronal control of skin function: The skin as a neuroimmunoendocrine organ. Physiol. Rev. 2006, 86, 1309-1379. [CrossRef] [PubMed]

47. Lundberg, J.M.; Modin, A. Inhibition of sympathetic vasoconstriction in pigs in vivo by the neuropeptide Y-Y1 receptor antagonist BIBP 3226. Br. J. Pharmacol. 1995, 116, 2971-2982. [CrossRef] [PubMed]

48. Padilla, J.; García-Villalón, A.L.; Monge, L.; García, J.L.; Fernández, N.; Gómez, B.; Diéguez, G. Peptidergic modulation of the sympathetic contraction in the rabbit ear artery: Effects of temperature. Br. J. Pharmacol. 1997, 121, 21-28. [CrossRef] [PubMed]

49. Wallengren, J. Vasoactive peptides in the skin. J. Investig. Dermatol. Symp. Proc. 1997, 2, 49-55. [CrossRef] [PubMed]

50. Levine, J.D.; Taiwo, Y.O.; Collins, S.D.; Tam, J.K. Noradrenaline hyperalgesia is mediated through interaction with sympathetic postgahglionic neurone terminals rather than activation of primary afferent nociceptors. Nature 1986, 323, 158-160. [CrossRef] [PubMed]

51. Drummond, P.D. Noradrenaline increases hyperalgesia to heat in skin sensitized by capsaicin. Pain 1995, 60, 311-315. [CrossRef]

52. Gibbs, J.L.; Flores, C.M.; Hargreaves, K.M. Attenuation of capsaicin-evoked mechanical allodynia by peripheral neuropeptide Y Y1 receptors. Pain 2006, 124, 167-174. [CrossRef] [PubMed]

53. Magnussen, C.; Hung, S.P.; Ribeiro-da-Silva, A. Novel expression pattern of neuropeptide Y immunoreactivity in the peripheral nervous system in a rat model of neuropathic pain. Mol. Pain 2015, 11, 31. [CrossRef] [PubMed]

54. Franke-Radowiecka, A.; Wąsowicz, K.; Klimczuk, M.; Podlasz, P.; Zalecki, M.; Sienkiewicz, W. Immunohistochemical Characterization of Sympathetic Chain Ganglia (SChG) Neurons Supplying the Porcine mammary Gland. Anat Histol. Embryol. 2016, 45, 44-50. [CrossRef] [PubMed]

55. Johansson, O.; Vaalasti, A. Immunohistochemical evidence for the presence of somatostatin-containing sensory nerve fibres in the human skin. Neurosci. Lett. 1987, 73, 225-230. [CrossRef] 
56. Dalsgaard, C.J.; Jernbeck, J.; Stains, W.; Kjartansson, J.; Haegerstrand, A.; Hökfelt, T.; Brodin, E.; Cuello, A.C.; Brown, J.C. Calcitonin gene-related peptide-like immunoreactivity in nerve fibers in the human skin. Relation to fibers containing substance $\mathrm{P}$-, somatostatin- and vasocactive intestinal polypeptide-like immunoreactivity. Histochemistry 1989, 91, 35-38. [CrossRef] [PubMed]

57. Szolcsányi, J.; Helyes, Z.; Oroszi, G.; Németh, J.; Pintér, E. Release of somatostatin and its role in the mediation of the anti-inflammatory effect induced by antidromic stimulation of sensory fibres of rat sciatic nerve. Br. J. Pharmacol. 1998, 123, 936-942. [CrossRef] [PubMed]

58. Carlton, S.M.; Du, J.; Zhou, S.; Coggeshall, R.E. Tonic control of peripheral cutaneous nociceptors by somatostatin receptors. J. Neurosci. 2001, 21, 4042-4049. [PubMed]

59. Botti, M.; Gazza, F.; Ragionieri, L.; Minelli, L.B.; Panu, R. Double labelling immunohistochemistry on the sympathetic trunk ganglia neurons projecting to the extrinsic penile smooth musculature of the pig: An experimental study on the retractor penis muscle. Ital. J. Anat. Embryol. 2013, 118, 223-239. [PubMed]

60. Ibba-Manneschi, L.; Niissalo, S.; Milia, A.F.; Allanore, Y.; Del Rosso, A.; Pacini, A.; Manetti, M.; Toscano, A.; Cipriani, P.; Liakouli, V.; et al. Variations of neuronal nitric oxide synthase in systemic sclerosis skin. Arthritis Rheumatol. 2006, 54, 202-213. [CrossRef] [PubMed]

61. Kellogg, D.L.; Zhao, J.L.; Wu, Y. Neuronal nitric oxide synthase control mechanisms in the cutaneous vasculature of humans in vivo. J. Physiol. 2008, 586, 847-857. [CrossRef] [PubMed]

62. Houghton, B.L.; Meendering, J.R.; Wong, B.J.; Minson, C.T. Nitric oxide and noradrenaline contribute to the temperature threshold of the axon reflex response to gradual local heating in humanskin. J. Physiol. 2006, 572, 811-820. [CrossRef] [PubMed]

63. Gazza, F.; Acone, F.; Botti, M.; Ragionieri, L.; Panu, R.; Bo Minelli, L.; Palmieri, G. Double labelling immunohistochemistry on the peripheral autonomic neurons projecting to the bulbospongiosus muscle in male impuberal pigs. Vet. Res. Commun. 2003, 27, 603-605. [CrossRef] [PubMed]

64. Ragionieri, L.; Botti, M.; Gazza, F.; Bo Minelli, L.; Acone, F.; Panu, R.; Palmieri, G. Double labelling immunohistochemical characterization of autonomic sympathetic neurons innervating the sow retractor clitoridis muscle. Eur. J. Histochem. 2008, 52, 29-38. [CrossRef] [PubMed]

65. Eide, K.; Hole, K. Interactions between substance $P$ and norepinephrine in the regulation of nociception in mouse spinal cord. Pharmacol. Toxicol. 1992, 70, 397-401. [CrossRef] [PubMed]

66. Wong, B.J.; Tublitz, N.J.; Minson, C.T. Neurokinin-1 receptor desensitization to consecutive microdialysis infusions ofsubstancePin human skin. J. Physiol. 2005, 568, 1047-1056. [CrossRef] [PubMed]

67. Hill, E.L.; Elde, R. Vasoactive intestinal peptide distribution and colocalization with dopamine- $\beta$-hydroxylase in sympathetic chain ganglia of pig. J. Auton. Nerv. Syst. 1989, 27, 229-239. [CrossRef]

68. Lundberg, J.M.; Änggärd, A.; Fahrenkrug, J.T.; Hökfelt, V.M. Vasoactive intestinal polypeptide in cholinergic neurons of exocrine glands: Functional significance of coexisting transmitters for vasodilation and secretion. Proc. Natl. Acad. Sci. USA 1980, 77, 1651-1655. [CrossRef] [PubMed]

69. Stanke, M.; Geissen, M.; Götz, R.; Ernsberger, U.; Rohrer, H. The early expression of VAChT and VIP in mouse sympathetic ganglia is not induced by cytokines acting through LIFR $\beta$ or CNTFR $\alpha$. Mech. Dev. 2000, 91, 91-96. [CrossRef]

70. Hartschuh, W.; Weihe, E.; Reinecke, M. Peptidergic (neurotensin, VIP, substance P) nerve fibres in the skin. Immunohistochemical evidence of an involvement of neuropeptides in nociception, pruritus and inflammation. Br. J. Dermatol. 1983, 109, 14-17. [CrossRef] [PubMed]

71. Schulze, E.; Witt, M.; Fink, T.; Hofer, A.; Funk, R.H. Immunohistochemical detection of human skin nerve fibers. Acta Histochem. 1997, 99, 301-309. [CrossRef]

72. Bennett, L.A.; Johnson, J.M.; Stephens, D.P.; Saad, A.R.; Kellogg, D.L., Jr. Evidence for a role for vasoactive intestinal peptide in active vasodilatation in the cutaneous vasculature of humans. J. Physiol. 2003, 552, 223-232. [CrossRef] [PubMed]

73. Wilkins, B.W.; Chung, L.H.; Tublitz, N.J.; Wong, B.J.; Minson, C.T. Mechanisms of vasoactive intestinal peptide-mediated vasodilation in human skin. J. Appl. Physiol. 2004, 97, 1291-1298. [CrossRef] [PubMed]

74. Szabo, B.; Hedler, L.; Ensinger, H.; Starke, K. Opioid peptides decrease noradrenaline release and blood pressure in the rabbit at peripheral receptors. Naunyn Schmiedebergs Arch. Pharmacol. 1986, 332, 50-56. [CrossRef] [PubMed]

75. Chahl, L.A. Opioids-Mechanisms of action. Exp. Clin. Pharmacol. 1996, 19, 63-65. [CrossRef] 
76. Shioda, S.; Yada, T.; Muroya, S.; Uramura, S.; Nakajo, S.; Ohtaki, H.; Hori, T.; Shimoda, Y.; Funahashi, H. Functional significance of colocalization of PACAP and catecholamine in nerve terminals. Ann. N. Y. Acad. Sci. 2000, 921, 211-217. [CrossRef] [PubMed]

77. Steinhoff, M.; McGregor, G.P.; Radleff-Schlimme, A.; Steinhoff, A.; Jarry, H.; Schmidt, W.E. Identification ofpituitary adenylate cyclase activating polypeptide (PACAP) and PACAP type 1 receptor in human skin: Expression of PACAP-38 is increased in patients with psoriasis. Regul. Pept. 1999, 80, 49-55. [CrossRef]

78. Warren, J.B.; Larkin, S.W.; Coughlan, M.; Kajekar, R.; Williams, T.J. Pituitary adenylate cyclase activating polypeptide is a potent vasodilator and oedema potentiator in rabbit skin in vivo. Br. J. Pharmacol. 1992, 106, 331-334. [CrossRef] [PubMed]

79. Cardell, L.O.; Stjärne, P.; Wagstaff, S.J.; Agustí, C.; Nadel, J.A. PACAP-induced plasma extravasation in rat skin. Regul. Pept. 1997, 71, 67-71. [CrossRef]

80. Tainio, H.; Vaalasti, A.; Rechardt, L. The distribution of substance P-, CGRP-, galanin- and ANP-like immunoreactive nerves in human sweat glands. Histochem. J. 1987, 19, 375-380. [CrossRef] [PubMed]

81. Kofler, B.; Berger, A.; Santic, R.; Moritz, K.; Almer, D.; Tuechler, C.; Lang, R.; Emberger, M.; Klausegger, A.; Sperl, W.; et al. Expression of neuropeptide galanin and galanin receptors in human skin. J. Investig. Dermatol. 2004, 122, 1050-1053. [CrossRef] [PubMed]

82. Schmidhuber, S.M.; Rauch, I.; Kofler, B.; Brain, S.D. Evidence that the modulatory effect of galanin on inflammatory edema formation is mediated by the galanin receptor 3 in the murine microvasculature. J. Mol. Neurosci. 2009, 37, 177-181. [CrossRef] [PubMed]

83. Holmberg, K.; Kuteeva, E.; Brumovsky, P.; Kahl, U.; Karlström, H.; Lucas, G.A.; Rodriguez, J.; Westerblad, H.; Hilke, S.; Theodorsson, E.; et al. Generation and phenotypic characterization of a galanin overexpressing mouse. Neuroscience 2005, 133, 59-77. [CrossRef] [PubMed]

84. Brumovsky, P.; Hygge-Blakeman, K.; Villar, M.J.; Watanabe, M.; Wiesenfeld-Hallin, Z.; Hökfelt, T. Phenotyping of sensory and sympathetic ganglion neurons of a galanin-overexpressing mouse-Possible implications for pain processing. J. Chem. Neuroanat. 2006, 31, 243-262. [CrossRef] [PubMed]

(C) 2017 by the authors. Licensee MDPI, Basel, Switzerland. This article is an open access article distributed under the terms and conditions of the Creative Commons Attribution (CC BY) license (http:/ / creativecommons.org/licenses/by/4.0/). 